\title{
Age, microfacies and depositional environment of the Middle to Late Paleocene shallow-marine carbonates in the Sirt Basin of Libya (Upper Sabil Formation): "Are Intisar domal structures pinnacle reefs?"
}

\author{
A. Vršič ${ }^{1}$ (1) - H.-J. Gawlick ${ }^{1}$ F. Schlagintweit ${ }^{2} \cdot$ E. Machaniec $^{3} \cdot$ M. Gharsalla $^{4}$
}

Received: 18 December 2020 / Accepted: 11 August 2021 / Published online: 28 August 2021

(c) The Author(s) 2021

\begin{abstract}
In the central-eastern Sirt Basin, enigmatic Intisar domal structures host significant hydrocarbon accumulations. These structures have been commonly interpreted as pinnacle reefs/bioherms occurring in the open-marine basinal environment. Generally, pinnacle reefs/bioherms are mainly characterized by in situ carbonates. The current study challenges the Intisar pinnacle reef/bioherm model by examining one of the domal structures in terms of biostratigraphy, microfacies and depositional environment. These structures were dated using larger benthic foraminifera, which yielded a Middle to Late Paleocene age (Selandian-Early Thanetian). Thirteen microfacies types representing different carbonate ramp environments ranging from outer ramp to inner ramp, were defined. Outer ramp deposits have been observed adjacent to the domal structure, represented mainly by wackestone with small benthic and planktonic foraminifera. The outer ramp deposits are most likely isochronous to the domal structures. The lower part of the domal structures is composed mainly of foraminiferal-algal-echinodermal packstones. The upper part is characterized by foraminiferal-algal-echinodermal packstones with intercalated microbialite-coral boundstones. The euphotic inner ramp deposits are preserved on the crest of the domal structure, consisting of grainstone and packstone rich in Glomalveolina. As a result of this study, the Intisar domal structures are seen as erosional relics of a carbonate ramp and no evidence for pinnacle reef/bioherm model was found.
\end{abstract}

Keywords Western Tethys $\cdot$ Microfacies analysis $\cdot$ Biostratigraphy $\cdot$ Larger benthic foraminifera $\cdot$ Depositional geometry

\section{Introduction}

The Sirt Basin (Fig. 1a, b) is one of the most prolific hydrocarbon provinces globally, and the important reservoir rocks are Middle to Late Paleocene shallow-marine carbonates (Ahlbrandt 2001). Although this time interval has been studied intensively by various authors concerning the

A. Vršič

89alesvrsic@gmail.com

1 Department of Applied Geosciences and Geophysics, Montanuniversität Leoben, Peter-Tunner Strasse 5, 8700 Leoben, Austria

2 Lerchenauerstrasse 167, 80935 Munich, Germany

3 Faculty of Geography and Geology, Institute of Geological Sciences, Jagiellonian University, Gronostajowa 3a, 30-387 Kraków, Poland

4 Engineering Planning Department, Fourth Floor, Zueitina Oil Company, Sidi Issa Street, P.O. Box 2134, Tripoli, Libya architecture of the carbonate reservoirs (Terry and Williams 1969; Bebout and Pendexter 1975; Brady et al. 1980; Gumati 1992; Mresah 1993, 1998; Spring and Hansen 1998), little information has actually been given regarding the detailed biostratigraphy, microfacies, depositional environment and geometry.

The domal structures of the shallow-marine carbonates in the Intisar embayment were interpreted, mainly based on seismic and sedimentological studies (Terry and Williams 1969; Brady et al. 1980; Gumati 1992), as Intisar pinnacle reefs/bioherms in a deep-marine basinal environment (Figs. 1c, 2). Terry and Williams (1969) refer to the domal structures as bioherms composed of a basal algal-foraminiferal member (carbonate bank) with a dominantly packstone texture. The algal-foraminiferal member is overlain by a coral member with corals embedded in a micritic matrix. According to its original definition (Cumings and Shrock 1928 , p. 599), bioherm is "a dome-like, lens-like or other circumscribed mass built exclusively or mainly by sedentary organisms and enclosed in normal rock of different 


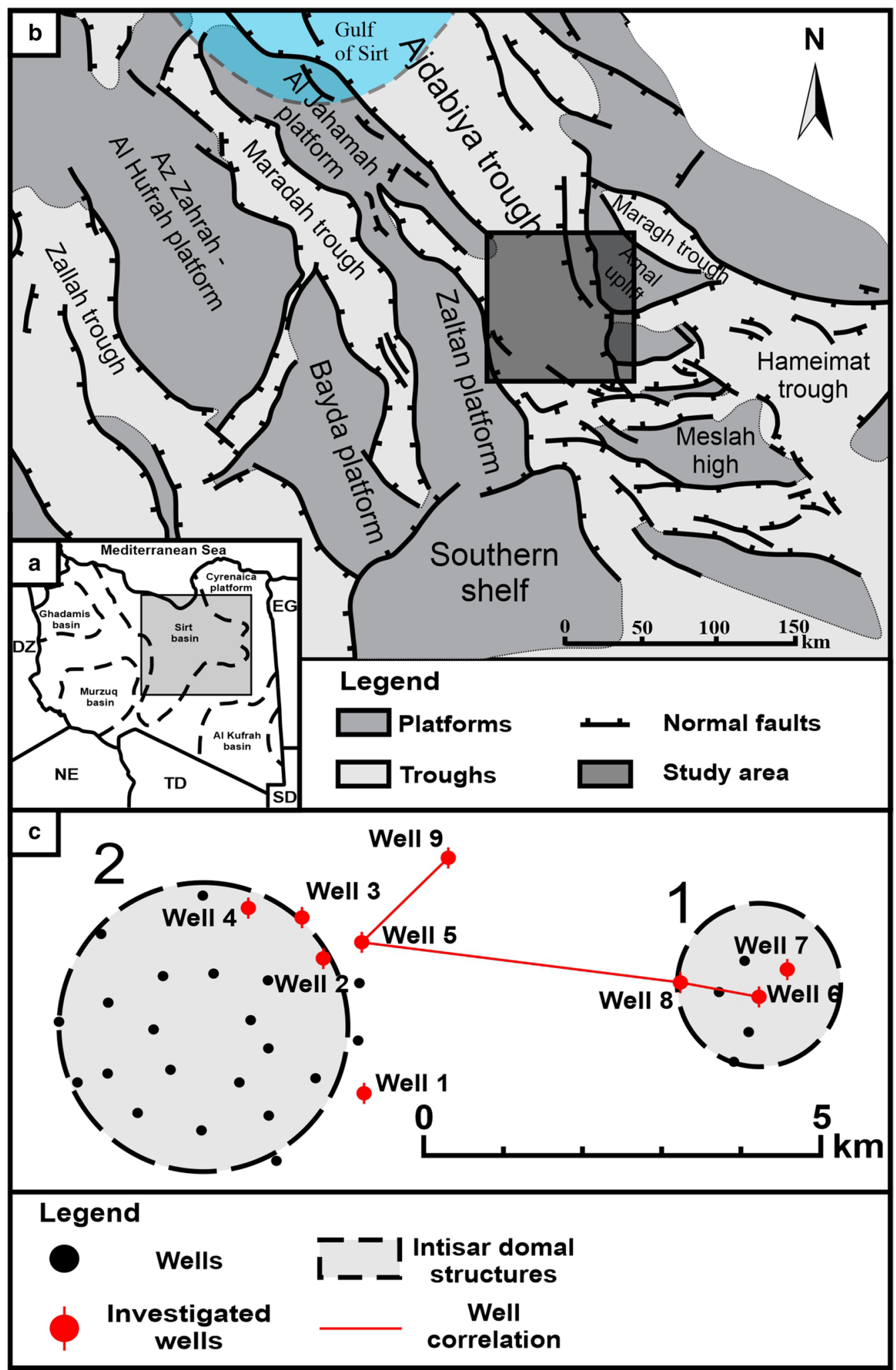

Fig. 1 a Regional map of Libya with sedimentary basins indicated by the dashed line and countries bordering Libya ( $D Z$ Algeria, $E G$ Egypt, $N E$ Niger, $T D$ Chad, $T N$ Tunisia). b Structural elements of the Sirt Basin. Marked are the small- and medium-sized horst (medium grey colour) structures. Troughs are marked with light grey, and the local highs were not considered. The square indicates the study area.
The map is redrawn and modified after Rusk (2001). c Sketch map of Intisar domal strutures 1 and 2 with indicated locations of the nine investigated wells (Well 1-9). With black dots are indicated locations of other wells that have been drilled in the past and are not included in this study 
lithological character". Algal-foraminiferal member sensu Terry and Williams (1969) cannot be part of a bioherm according to the original definition, but represents a different depositional environment.

Brady et al. (1980) described a more complex structure of the Intisar D reservoir as a pinnacle reef consisting of algal-foraminiferal biomicrite and coral biolithite. Pinnacle reef is not a clearly defined term. According to Wilson (1975), a pinnacle reef is a conical or steep-sided upward tapering mound or reef. A knoll or pinnacle is used by Wilson (1974) to denote a quiet water reef. Algal-foraminiferal biomicrite and coral biolithite sensu Brady et al. (1980) are entirely different microfacies types, and clearly, the algal-foraminiferal biomicrite cannot be included in reefal facies.

The conception of pinnacle reefs/bioherms was most likely derived from coral-rich facies and seismic data, which show oval buildups (e.g. Brady et al. 1980), but corals can inhabit various carbonate depositional environments (details in Zamagni et al. 2012). In general, during the Paleogene, corals were thriving together with red algae in the mesophotic zone, where photosynthesis rates are much slower. Corals living under reduced light conditions could not accrete at rates comparable to modern reefs in the euphotic zone (Pomar et al. 2017). There are also reports of coral bioconstructions from the euphotic zone (Bosellini and Russo 1992; Vescogni et al. 2016; Bosellini et al. 2020). The studies mentioned above (e.g. Terry and Williams 1969; Brady et al. 1980; Gumati 1992) did not consider the growth form of corals as an indicator of water turbidity and sedimentation rate to constrain better the depositional conditions (Sanders and Baron-Szabo 2005). The pinnacle reefs are supposed to be surrounded by isochronous deep-marine deposits (Gumati 1992). The age of these deposits is biostratigraphically poorly constrained and has not been correlated with the age of pinnacle reefs. The question of whether the deep-marine deposits are age equivalent with the shallow-marine domal structures or younger/older remains open. Nevertheless, the age relation of the deep-marine and shallow-marine deposits is crucial for reconstructing the depositional geometry.

No Middle to Late Paleocene pinnacle reef outcrop analogues, similar in terms of sedimentary evolution and facies association to the Intisar pinnacles, have been found. Middle to Late Paleocene pinnacle reefs/bioherms as such have been so far reported only from the Intisar embayment (Fig. 2).

The exact age and depositional geometry of these shallow-marine carbonates are questionable due to the scarcity of biostratigraphic and microfacies data. Today's commonly used interpretations (Terry and Williams 1969; Brady et al. 1980) are based on studies mainly before modern microfacies analysis was extensively established (Flügel 1982, 2004). Besides, in the last decades, a detailed biozonal scheme has been erected to provide detailed biostratigraphic constraints of shallow-water sedimentary successions by means of benthic foraminifera with emphasis on several lineages belonging to the informal group of larger foraminifera (Less 1998; Less et al. 2007; Özcan et al. 2010; Papazzoni et al. 2017; Serra-Kiel et al. 1998, 2020).

This study demonstrates that the same vertical facies evolution described for these pinnacle reefs/bioherms (Terry and Williams 1969; Brady et al. 1980; Gumati 1992) can also be applied for a carbonate ramp model (Mresah 1993, 1998). Thin sections of samples (core and cuttings) from several wells penetrating the Intisar domal structures were studied. The aim of the present contribution is to date the sedimentary sequences, reconstruct the depositional environment and the geometry of the domal structures.

\section{Geological setting}

The Sirt Basin is a part of the African passive margin towards the Mediterranean Sea (Ionian Ocean) to the north (Fig. 1a). It is an extensional basin characterized by four major troughs: Zallah, Maradah, Ajdabiya, Hameimat and a minor Maragh trough (Fig. 1b). The troughs are separated by four major horsts: Al Jahamah, Az Zahrah-Al Hufrah, Bayda and Zaltan (Rusk 2001).

The Mesozoic-Cenozoic geodynamic evolution of the Sirt Basin has been widely debated, although a unanimous interpretation is still lacking (Harding 1984; Gras and Thusu 1998; Ambrose 2000; Pawellek 2009). The following geodynamic scenario was adopted here as the most routinely used: the latest Cretaceous (Maastrichtian) is characterized by tectonic quiescence. The deep-marine carbonates of the Kalash Formation covered both troughs and submerged horst regions, with relatively little change in terms of depositional environments (Abadi et al. 2008).

The Paleocene marks a new extensional phase of rapid tectonic subsidence due to crustal thinning, block faulting and regional dextral wrenching (El-Hawat and Pawellek 2004). Due to the variable rates of subsidence in this newly formed horst-and-graben structure, the facies variability became once again more pronounced during the Paleocene extensional phase. As a result of this tectonic phase, several shallow-marine and deep-marine depositional areas were established. From the Late Eocene to the present, a renewed subsidence occurred in the eastern part of the Sirt Basin due to thermal relaxation (Abadi et al. 2008).

The stratigraphic nomenclature of the Sirt Basin by Barr and Weegar (1972) is adopted herein (Fig. 3). The Upper Sabil Formation, routinely attributed to the Paleocene, is the focus of the present study. From the Cretaceous/Paleogene boundary onwards, the shallow-marine carbonate shelf of the Lower Sabil Formation developed in the eastern parts of the basin. In the west and central sector, the deep-marine 


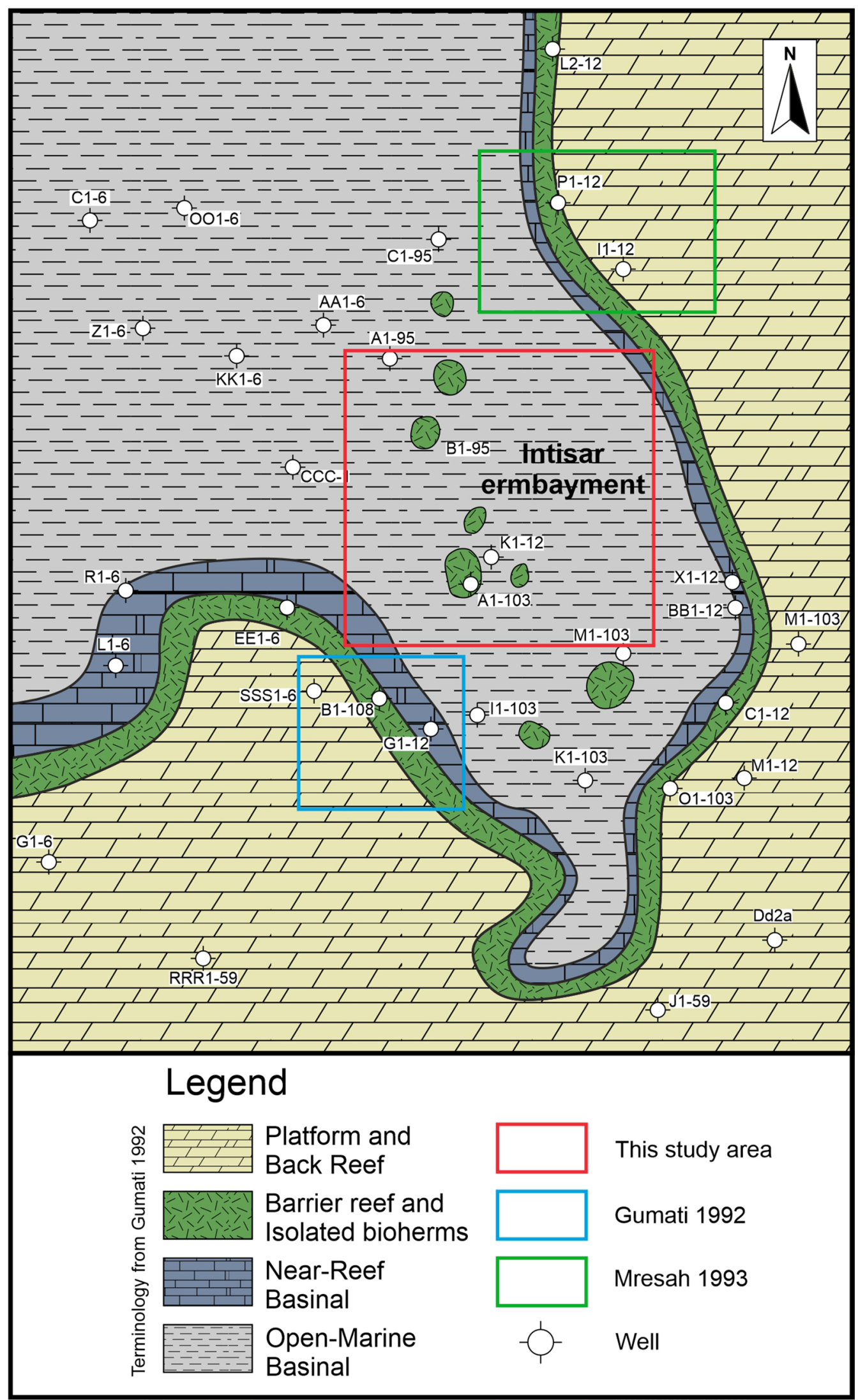


4Fig. 2 Lithofacies map of the Late Paleocene Upper Sabil Formation in the area of Intisar embayment. The map is redrawn after Gumati (1992). Lithofacies terminology in the legend after Gumati (1992) as a comparison. Well names, according to Gumati (1992). The study area is marked by a red square

Hagfa Formation was deposited. During the Middle Paleocene, the carbonates of the Lower Sabil Formation were transgressively overlain by the fine-grained siliciclastic Sheterat Formation (Barr and Weegar 1972; Banerjee 1980; Bezan 1996), followed again by shallow-marine carbonates, i.e. the Upper Sabil Formation. In the eastern sector, restricted shallow-marine facies with anhydrite developed (Hallett 2002). The Upper Sabil Formation is overlain by the deep-marine Harash/Kheir Formation. Due to the deepening trend, the shallow-marine carbonate production was largely restricted across the Sirt Basin. During the early Eocene, evaporites and dolomites of the Gir Formation were deposited in the southern and western sector, while the central sector is dominated by limestones (Barr and Weegar 1972; Abugares 1996). The Gir Formation is conformably overlain by the Middle Eocene Gialo Formation, representing a thick nummulitic limestone succession. The Augila Formation transgressively overlies the Gialo Formation (Hallett and Clark-Lowes 2016). The overlying deposits of the Arida, Diba and Marada Formations represent a siliciclastic-carbonate cycle.

Figure 3

The studied domal structures (Fig. 1c) are located in the central-eastern sector of the basin, the Ajdabiya trough (Fig. 1). According to Gumati (1992), the deep-water Intisar embayment, where isolated bioherms/pinnacle reefs (domal structures in this study) were growing (Fig. 2), is bounded by a rimmed carbonate platform with a barrier reef, fore-reef talus and a lagoon. Mresah (1993) studied the eastern margin of the Intisar embayment (Fig. 2). Whereas Gumati (1992) interpreted the eastern margin as a rimmed carbonate platform with a steep slope, Mresah (1993) clearly demonstrated that the eastern margin of the Intisar embayment is characterized by a carbonate ramp geometry with no evidence of a significant slope break. Spring and Hansen (1998) follow the interpretation of Gumati (1992) for the eastern margin; however, they introduce a carbonate ramp geometry in the $\mathrm{N}-\mathrm{S}$ direction across the Intisar embayment with pinnacle reefs thriving in an outer ramp setting.

\section{Materials and methods}

Core and drill cutting samples from nine wells (Fig. 1c) were investigated. One hundred and thirty-two thin sections were prepared from the core material and 177 thin sections from drill cuttings. The lithological interpretation of the investigated successions is based mainly on the study of drill cuttings, as the core coverage is mostly restricted. The lithological interpretation of the drill cuttings was made difficult due to the abundant cavings and drill-bit metamorphism (Langenkamp 1994; Wenger et al. 2009), as in particular wells up to $40 \%$ of cuttings were damaged. Lithological boundaries were accurately constrained with well log data.

Where only drill cuttings are available, there is uncertainty in the reconstruction and interpretation of lithological columns, especially in coarse-grained textures (e.g. rudstone, boundstone) due to the small size of the drill cuttings. For the description and interpretation of microfacies the following references were used: Flügel (2004), Zamagni et al. (2008, 2009), Afzal (2010), Di Carlo et al. (2010), Bagherpour and Vaziri (2012) and Benedetti (2018). For the foraminiferal identification the following references were used: Hottinger (1960), Butterlin and Monod (1969), Drobne (1977), Sirel (1998), Sirel and Acar (2008), Hottinger (2009), Hottinger (2014), Benedetti et al. (2018), Sirel and Deveciler (2018), Consorti and Köroğlu (2019), Vicedo et al. (2021) and Serra-Kiel et al. (2020). The investigated material and thin sections figured in this paper are stored at the University of Leoben, Department for Applied Geosciences and Geophysics.

The investigated wells usually start with the Sheterat Formation, followed by Upper Sabil Formation and topped by Harash/Kheir Formations. The significant thickness variability of the Upper Sabil Formation between wells 1-5 (Fig. 4) and wells 6-8 (Fig. 5) results from well location. Wells $1-5$ are located at the rim of the Intisar domal structure 2 (Fig. 1c), while wells 6-8 penetrated the central part of the Intisar domal structure 1 (Fig. 1c). Well 9 is adjacent to the Intisar domal structure 2. Wells 1-6 have been cored, and a detailed description of the cored intervals is illustrated in Fig. 6.

\section{Results}

\section{Biostratigraphy}

The Paleocene shallow-marine carbonates of the Upper Sabil Formation are dated using larger benthic foraminifera (mainly nummulitids, alveolinids and orthophragminids). For the Paleocene and Eocene, a continuous system of numbered units (shallow benthic zones-SBZ) was established (Serra-Kiel et al. 1998). Serra-Kiel et al. (2020) recently recalibrated the Paleocene SBZ. The SBZ scheme is characterized mainly by oppelzones, identified by the cooccurrence of phyletically unrelated taxonomic groups (Pignatti and Papazzoni 2017) that benefit from the increasing knowledge of shallow benthic foraminifera such as Miscellaneidae (Hottinger 2009; Di Carlo et al. 2010; Sirel 2012; 


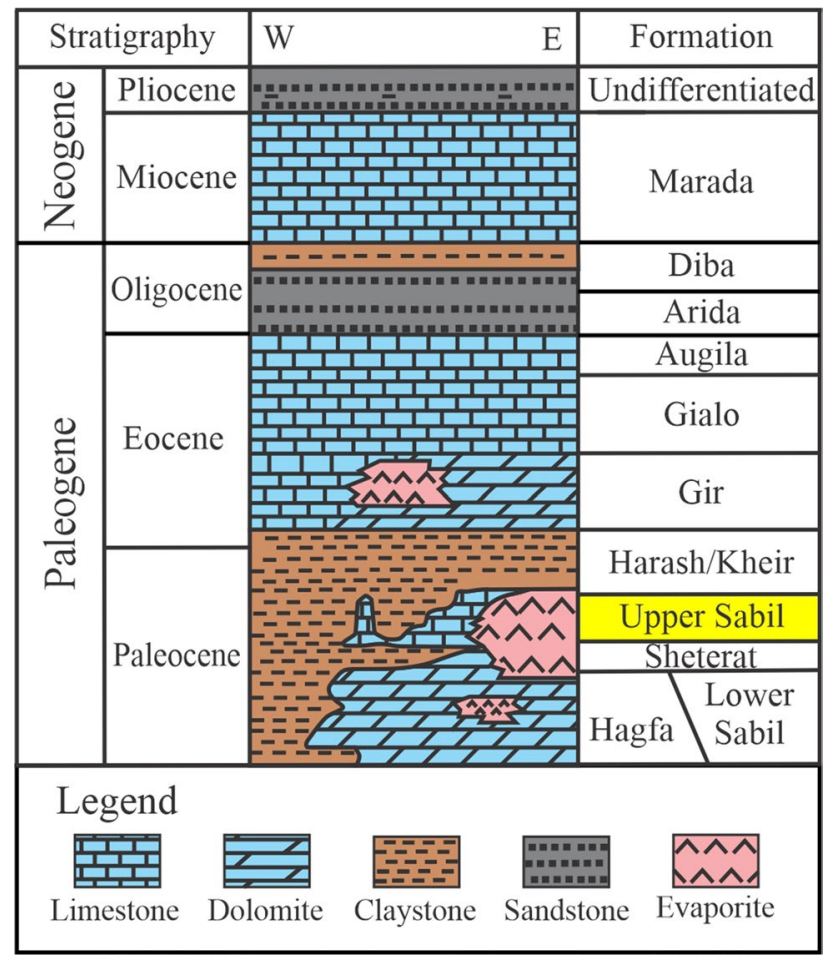

Fig. 3 Cenozoic sedimentary successions of the central-eastern part of the Sirt Basin. Modified after Swei (2010). The investigated shallow-marine carbonates of the Upper Sabil Formation are indicated with yellow colour. Stratigraphic nomenclature after Barr and Weegar (1972)

Benedetti et al. 2018), Rotaliidae (Hottinger 2014; Benedetti et al., 2018; Vicedo et al., 2021) and other as yet poorly known taxa (e.g. Benedetti et al. 2018, 2020). The Middle to Late Paleocene shallow-marine carbonate deposits of the Sirt Basin are dominated by Ranikothalia, miscellaneids and rotaliids, thus they can be successfully dated using Shallow Benthic Zonation.

Larger benthic foraminifera (LBF) from the Upper Sabil Formation were recently described by Vršič et al. (2021). Biostratigraphically important species are illustrated in Fig. 7. Their stratigraphic ranges are outlined in Fig. 8. Several index species of SBZ 3 were determined. A single specimen of Kathina cf. aquitanica was found. Kathina aquitanica Hottinger is an index taxon of SBZ 3 (Hottinger 2014). Serra-Kiel et al. (2020) extended the range of Kathina aquitanica from SBZ 2 to SBZ 4. Elazigina lenticula (Hottinger) is a widespread taxon, but has a wide stratigraphic range (SBZ 3-6, according to Hottinger 2014). Glomalveolina primaeva (Reichel) is the most widely recognized index taxon of the SBZ 3 among the presented foraminiferal assemblage (Serra-Kiel et al. 1998). Larger benthic foraminifera of the family Miscellaneidae Sigal are abundant constituents of the Middle-Late Paleocene shallow-marine environments. Two species were found: Miscellanea yvettae Leppig (sensu
Hottinger 2009) and Miscellanites primitivus (Rahaghi) (see Hottinger 2009). Both taxa are usually considered index fossils of SBZ 3 (Hottinger 2009), although Miscellanites primitivus has been recently reported by Consorti and Köroğlu (2019) from SBZ 2. Akbarina primitiva, erected by Sirel (2009), is considered a junior synonym of Miscellanites primitivus (e.g. Serra-Kiel et al. 2020) and is a marker of SBZ 2 in Turkey. Therefore, the most probable range of $M$. primitivus is within SBZ 2 and SBZ 3. Ranikothalia solimani Butterlin in Butterlin and Monod is the most abundant species and enables the correlation between the investigated wells. However, this taxon not yet has an unambiguous stratigraphical distribution. Rotorbinella hensoni (Smout) is constrained to SBZ 2 and SBZ 3 (Hottinger 2014), although Vicedo et al. (2021) suggested that $R$. detrecta (Hottinger) should be synonym of $R$. hensoni, thus extending its range up to SBZ1. Representatives of the family Discocyclinidae widely occur in the investigated foraminiferal assemblages. The Discocyclinidae first appeared in SBZ 3 (Less et al. 2007) and are essential constituents in the Eocene strata. The occurrence of unidentifiable Discocyclinidae in our samples is sufficient to support age determination as Selandian-Early Thanetian and refute the possibility that Upper Sabil Formation could be older than SBZ 3.

\section{Microfacies of the Upper Sabil Formation}

The petrographic analysis distinguished 13 microfacies types (MFT) labelled as MFT 1 to MFT 13 (Table 1).

MFT1 is a planktonic foraminiferal wackestone (Fig. 9a, b). The main bioclasts are planktonic foraminifera (Fig. 9a), small benthic foraminifera (Fig. 9b), ostracods and finegrained unidentifiable bioclasts.

MFT 2 is a fine-grained, foraminiferal-microbiodetritic packstone (Fig. 9c, d) consisting of LBF debris (mainly nummulitids), fine-grained unidentifiable bioclasts, planktonic foraminifera, small benthic foraminifera and rare echinoid spines.

MFT 3 is a foraminiferal-echinodermal packstone (Fig. 10a, b) and consists of echinoderms, small rotaliids, LBF and rare planktonic foraminifera. LBF are commonly fragmented and contribute to sediment accumulation as finegrained debris. Coralline algal crusts are mostly fragmented and rarely form bindstones with intergrowing acervulinids, planorbulinaceans, cyclostome bryozoans, serpulids, and peyssoneliacean algae.

MFT 4 is a foraminiferal-algal packstone (Fig. 11a, b) composed of LBF (nummulitids, orthophragminids, larger rotaliids and rare Glomalveolina), abundant fragmented coralline branches and rare coralline crusts. Lenticular orthophragminids are abundant, whereas flattened discoidal forms are scarce. Foraminiferal debris is coarser grained. Corals occur as fragments and are occasionally encrusted by thin 


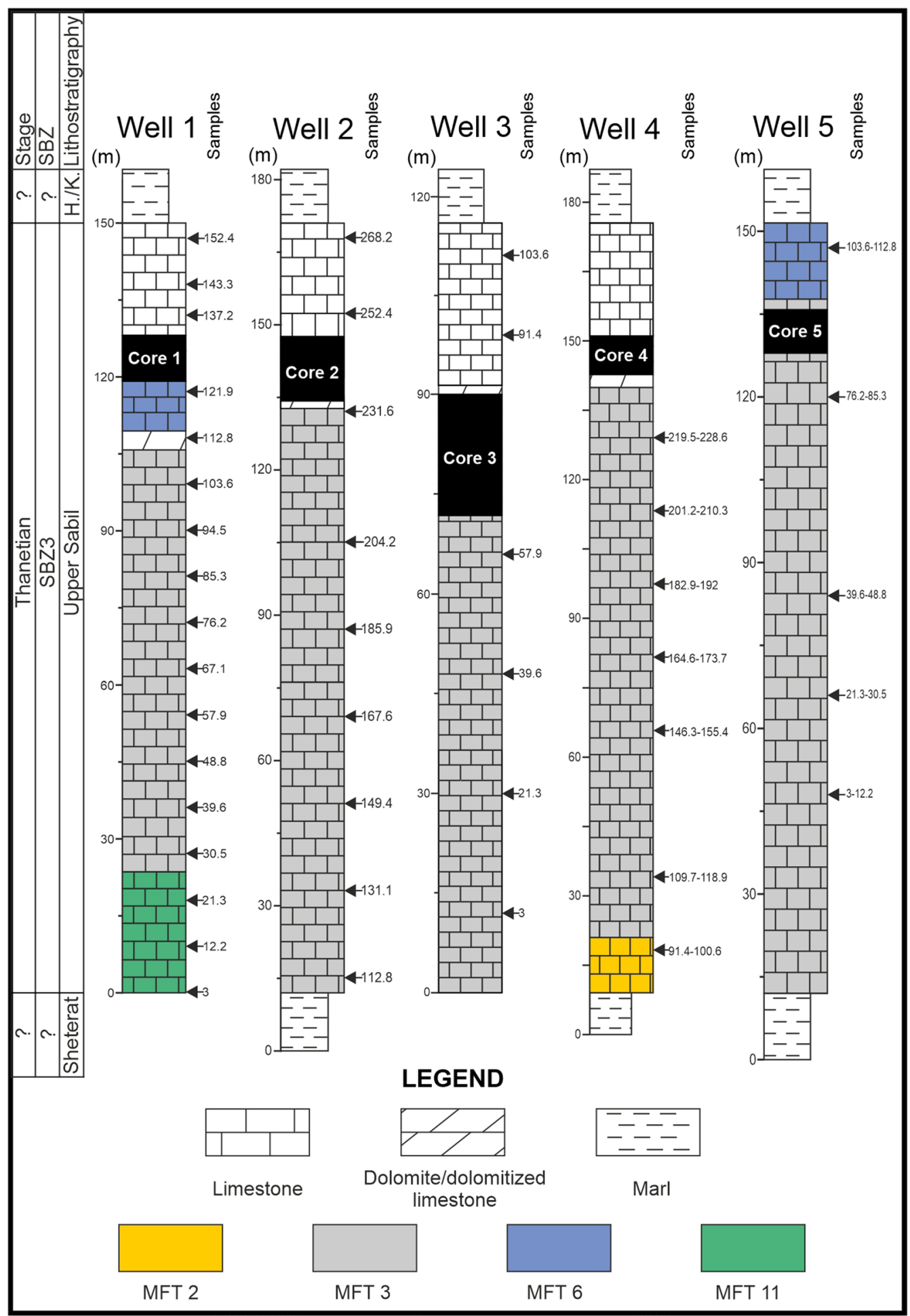

Fig. 4 Lithological columns reconstructed from drill cuttings for well 1 to well 5. The Upper Sabil Formation is underlain and overlain by deepmarine sediments of the Sheterat and Harash/Kheir (H./K.) Formations, respectively. Black rectangles indicate the position of the cored intervals

microbial crusts. Sometimes, foraminifera also exhibit micrite envelopes.

MFT 5 is a poorly sorted echinodermal-algal floatstone (Fig. 11c, d) with echinoderm debris, coralline algal branches, algal crust fragments, peysonneliaceans and rare LBF (orthophragminids and larger rotaliids).

MFT 6 is an unsorted orthophragminid-algal floatstone (Fig. 12a-h) and was encountered only in the upper parts 


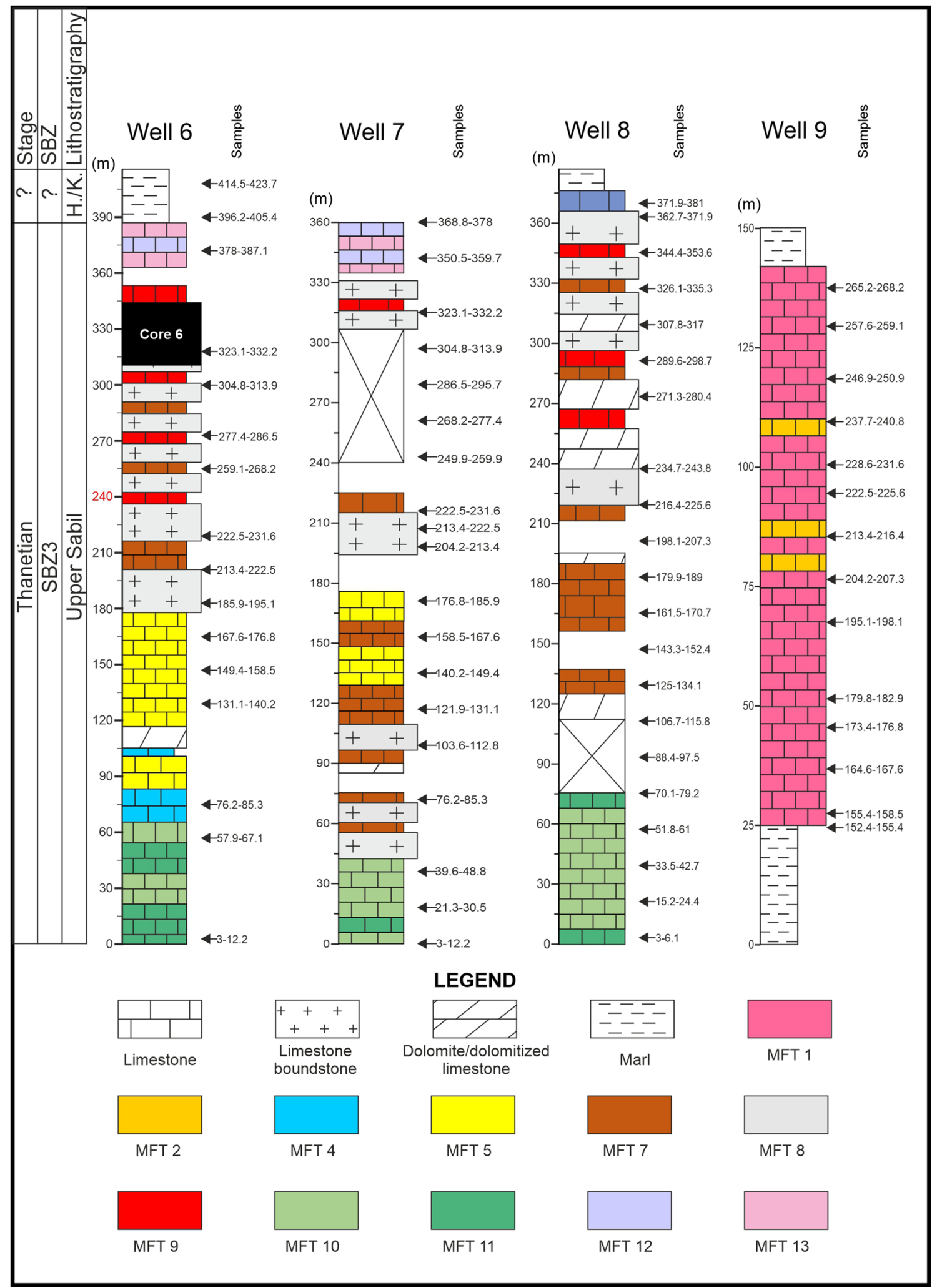

Fig. 5 Lithological columns reconstructed from drill cuttings for well 6 to well 8. The Upper Sabil Formation is underlain and overlain by deep-marine sediments of the Sheterat and Harash/Kheir (H./K.) For- mations, respectively. Black rectangle indicates the position of the cored interval for well 6 


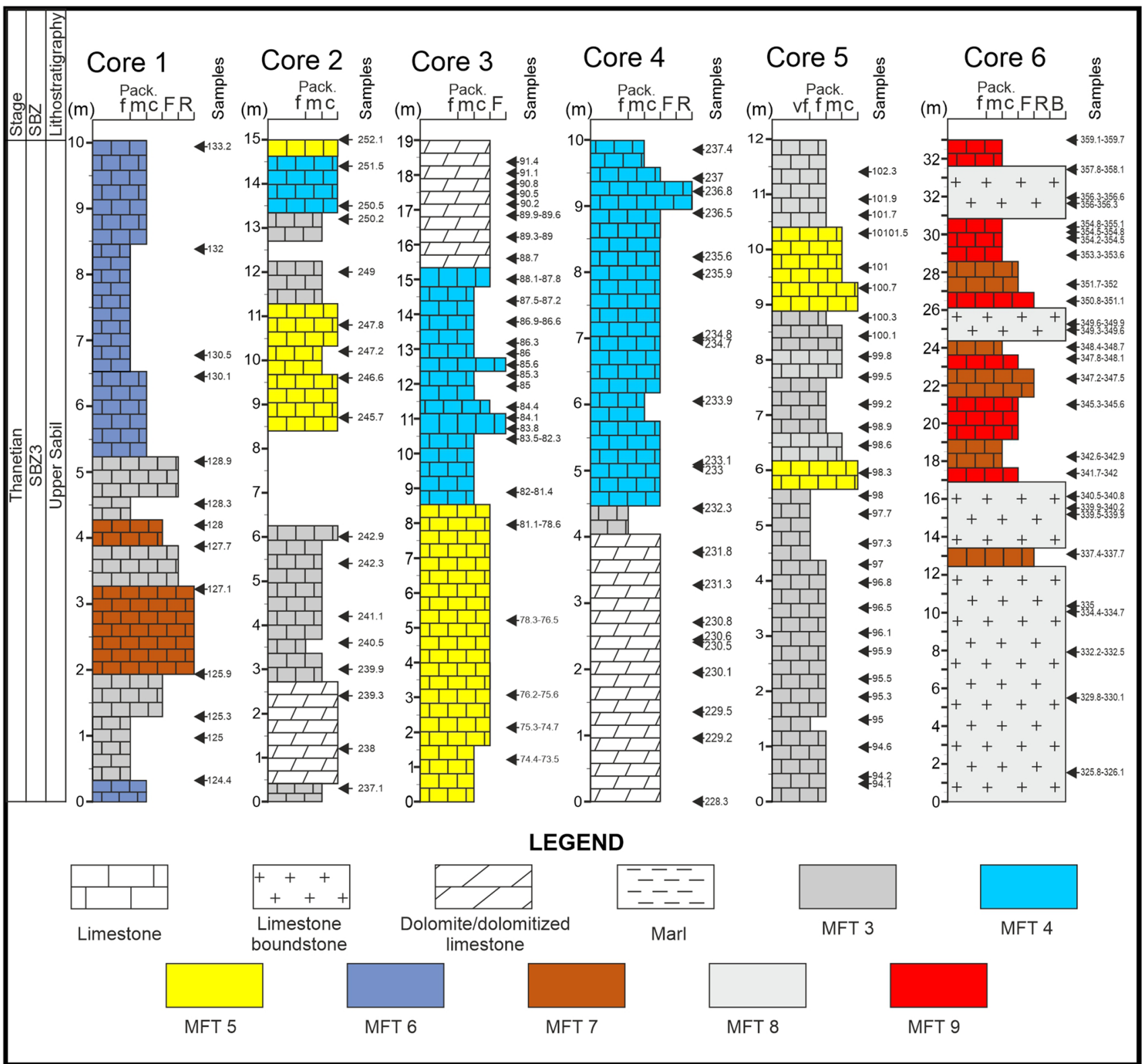

Fig. 6 A detailed description of the cored intervals for well 1 to well 6 . The width of the lithological column corresponds to different depositional textures according to Dunham (1962). Pack. packstone, of very fine, $f$ fine, $m$ middle-coarse, $c$ coarse, $F$ floatstone, $R$ rudstone, $B$ boundstone

macroborings, which are mostly filled with micrite. Microborings within the coralline algae are mostly hollow or cemented. In bioconstructor-dominated parts, the diversity of LBF is low.

MFT 7 is a poorly sorted, foraminiferal-bryozoan-algal floatstone (Fig. 13a-c), occasionally also bryozoan floatstone (Fig. 13d). The LBF assemblage consists of Ranikothalia solimani and Miscellanea yvettae; most of them are over $2 \mathrm{~mm}$ in size. Dendroid cyclostome bryozoans, echinodermal debris and fragmented coralline algal branches are subordinate bioclasts. 


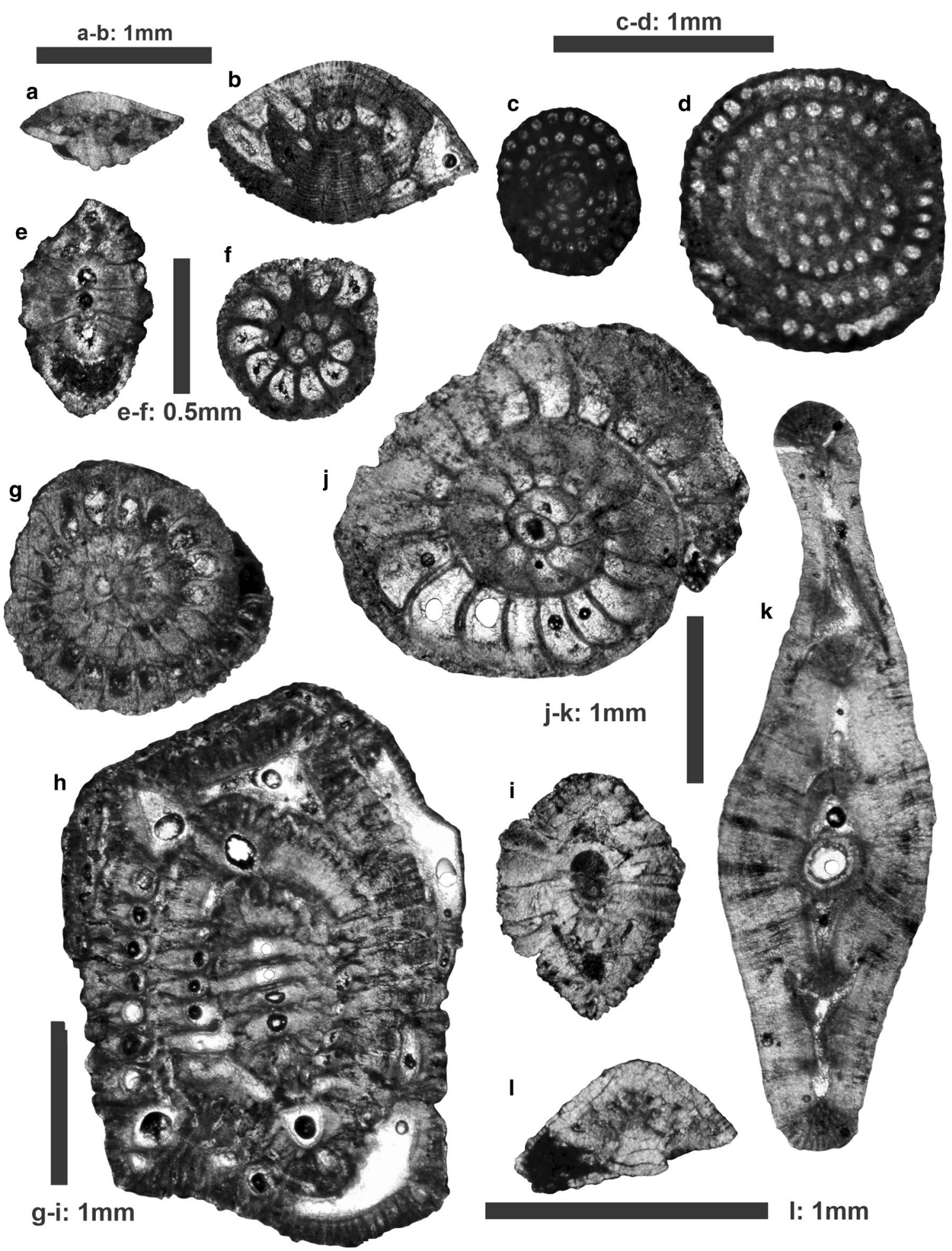

Fig. 7 Larger benthic foraminiferal assemblage from the Upper Sabil Formation. a Kathina cf. aquitanica. Sample well 1 (21.3). b Elazigina lenticula Hottinger. Sample well 2 (242.9). c, d Glomalveolina primaeva (Reichel). Sample well 7 (323.1-332.2). e-f Miscellanites primitivus (Rahaghi). e Sample well 4 (237.4); f Sample well 3 (234.7). g-i Miscellanea yvettae Leppig; g Sample well 2 (131.1);

h Sample well 6 (347.2-347.5); i Sample well 2 (204.2). j-k Ranikothalia solimani Butterlin in Butterlin and Monod; $\mathbf{j}$ Sample well 2 (240.5); k Sample well 6 (351.7-352). I Rotorbinella hensoni (Smout). Sample well 1 (30.5). Scale bars measure $1 \mathrm{~mm}$ for a-d, $\mathbf{g}-\mathbf{l}, 0.5 \mathrm{~mm}$ for $\mathbf{e}, \mathbf{f}$ 


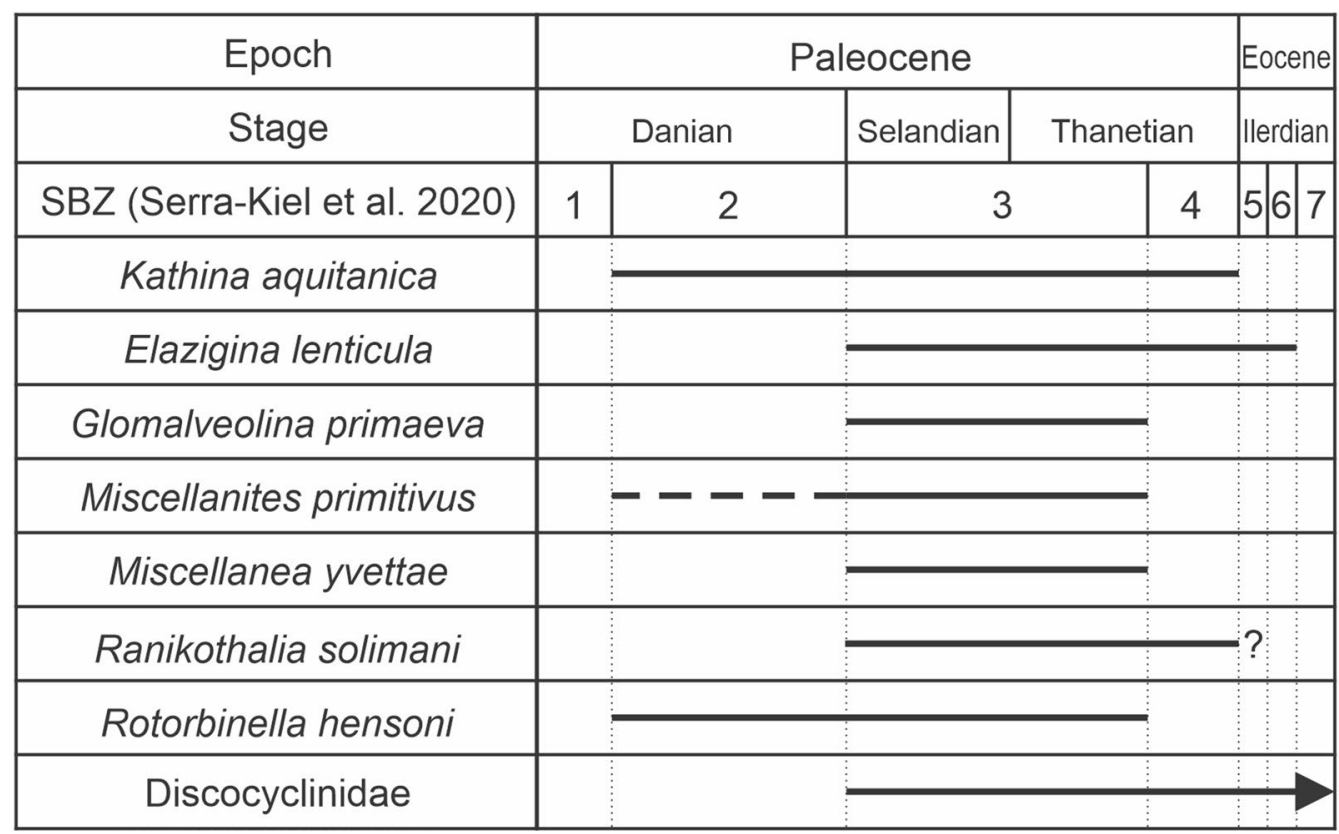

Fig. 8 Biostratigraphy of the Upper Sabil Formation is based on the larger benthic foraminifera. The shallow benthic zones (SBZ) for the Paleocene and Eocene follow recent recalibration by Serra-Kiel et al. (2020)

MFT 8 is an unsorted microbialite-coral boundstone. Corals play a minor role as bioconstructor. Abundant sedimentary matrix occurs between the boundstone. Microbialite microfabric terminology follows Zamagni et al. (2009). The following microbialite microfabrics were recognized: dense micrite (Fig. 14a), agglutinated microfabric (Fig. 14a, b), and clotted/peloidal microfabric (Fig. 14c). The agglutinated components consist of fine-grained debris and various larger bioclasts, e.g. LBF, echinoid spines, bryozoans and echinoderms. The microbialites are enveloped by encrusting laminar, plocoid/cerioid corals (Fig. 13a). Corals are also embedded in dense micrite (Fig. 14b). The microbialites are very rarely encrusted by intergrowing, thin coralline crusts and acervulinids (Fig. 14d).

Different coral morphotypes are intergrowing with microbialites. The most common are massive and encrusting cerioid/plocoid corals of Actinacis-type (Fig. 14e) and Goniopora-type assemblages. Phaceloid/dendroid corals are represented mainly by Oculina-type assemblage (Fig. 14f). The sedimentary matrix represents a volumetrically significant component of the boundstone microfacies. The contact between the sedimentary matrix and microbialites is mostly gradual. Occasionally, it is difficult to distinguish between sedimentary matrix and microbialites as the latter may agglutinate large bioclasts, e.g. LBF.

MFT 9 is densely packed, well to moderately sorted miscellaneid-foraminiferal-algal packstone (Fig. 15a, d) with miscellaneids, Ranikothalia solimani, lenticular orthophragminids (Fig. 15d), larger rotaliids, miliolids and textulariids.
Other bioclasts are coralline branches and rare coralline crusts, rare peyssoneliacean crust fragments, oyster shells and echinoderms. Some bioclasts exhibit micrite envelopes.

MFT 10 is a moderately to poorly sorted rotaliid-algal packstone (Fig. 16a-c) consisting of larger rotaliids, nongeniculate and geniculate coralline algae, peyssoneliacean algae, solenoporacean algae Parachaetetes asvapati Rao and Pia (Fig. 16c), serpulids, miliolid foraminifera, echinoderms, cidaroid spine and rare fragments of plocoid/cerioid corals. Bioclasts commonly exhibit a micritic envelope.

MFT 11 is a moderately sorted rotaliid-algal grainstone (Fig. 16d) with micritized grains, larger rotaliids, geniculate and non-geniculate coralline algae. Circumgranular, scalenohedral calcite cement represents the first generation of calcite cement followed by pore-filling blocky calcite cement (Fig. 16d).

MFT 12 consists of a moderately sorted, Glomalveolina-bioclastic grainstone (Fig. 17a-c) with Glomalveolina, large and small porcelaneous taxa, rotaliids, micritized grains, aggregate grains and Distichoplax biserialis (Fig. 17b). A high proportion of the grains exhibit a thin micrite envelope. The grains are rimmed by first-generation circumgranular cement consisting of equidimensional calcite crystals. However, this cement is poorly preserved and overprinted by a later pore-filling drusy to blocky calcite spar. Echinoderms are overgrown by syntaxial calcite cement, which also engulfs other grains as poikilotopic cement.

MFT 13 is a moderately to poorly sorted Glomalveolina-bioclastic packstone (Fig. 17d-h), consisting of 


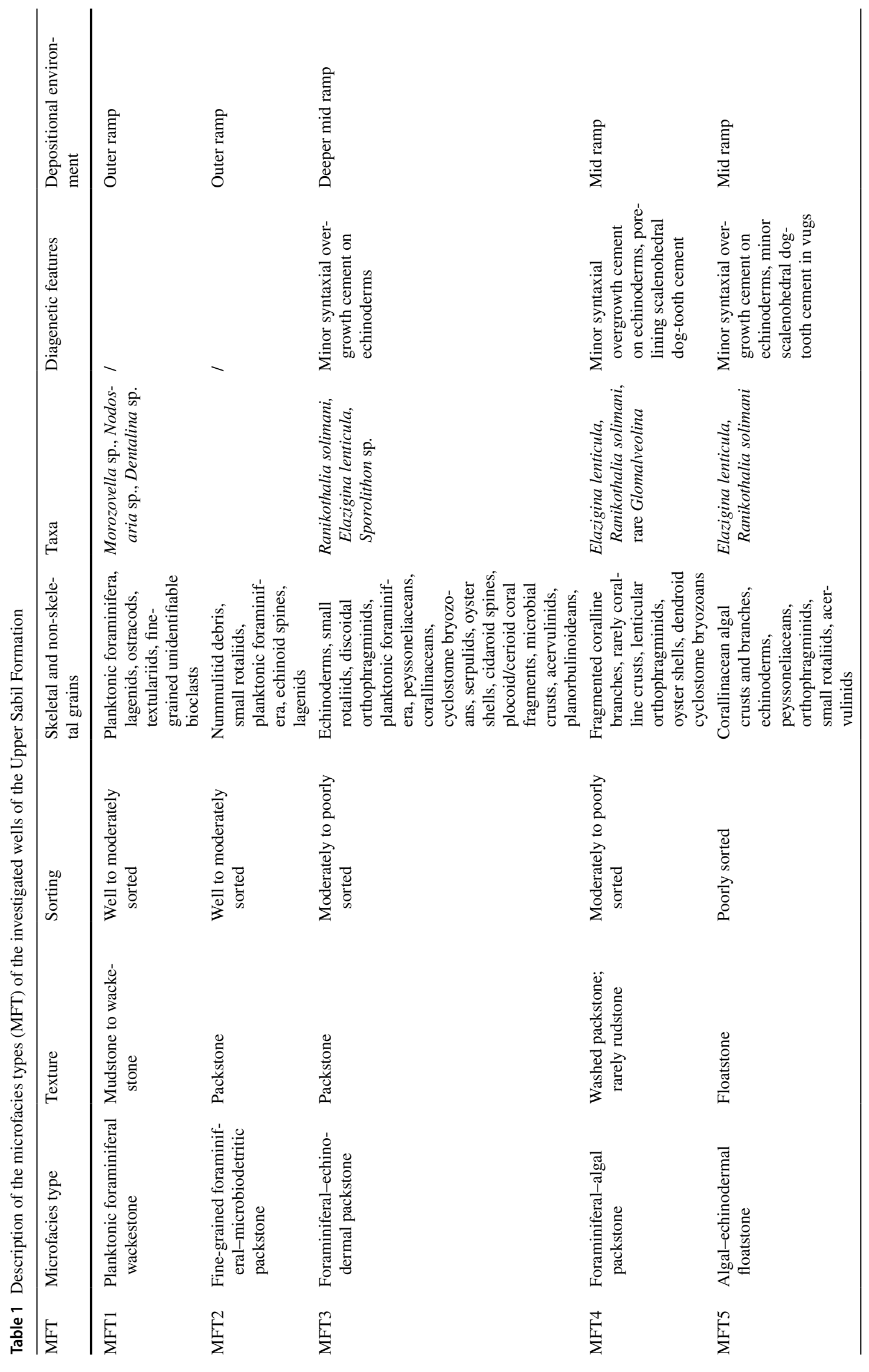




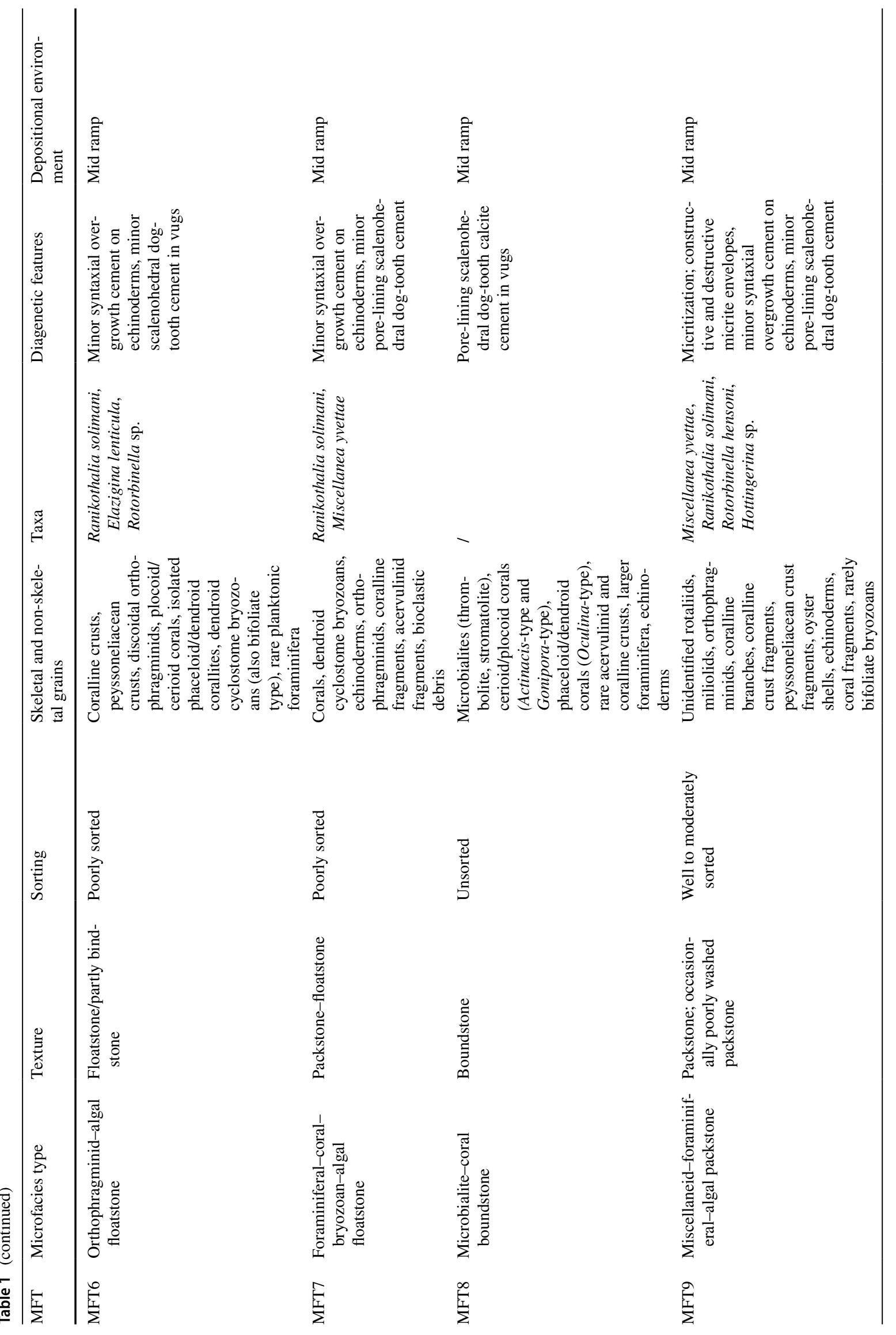




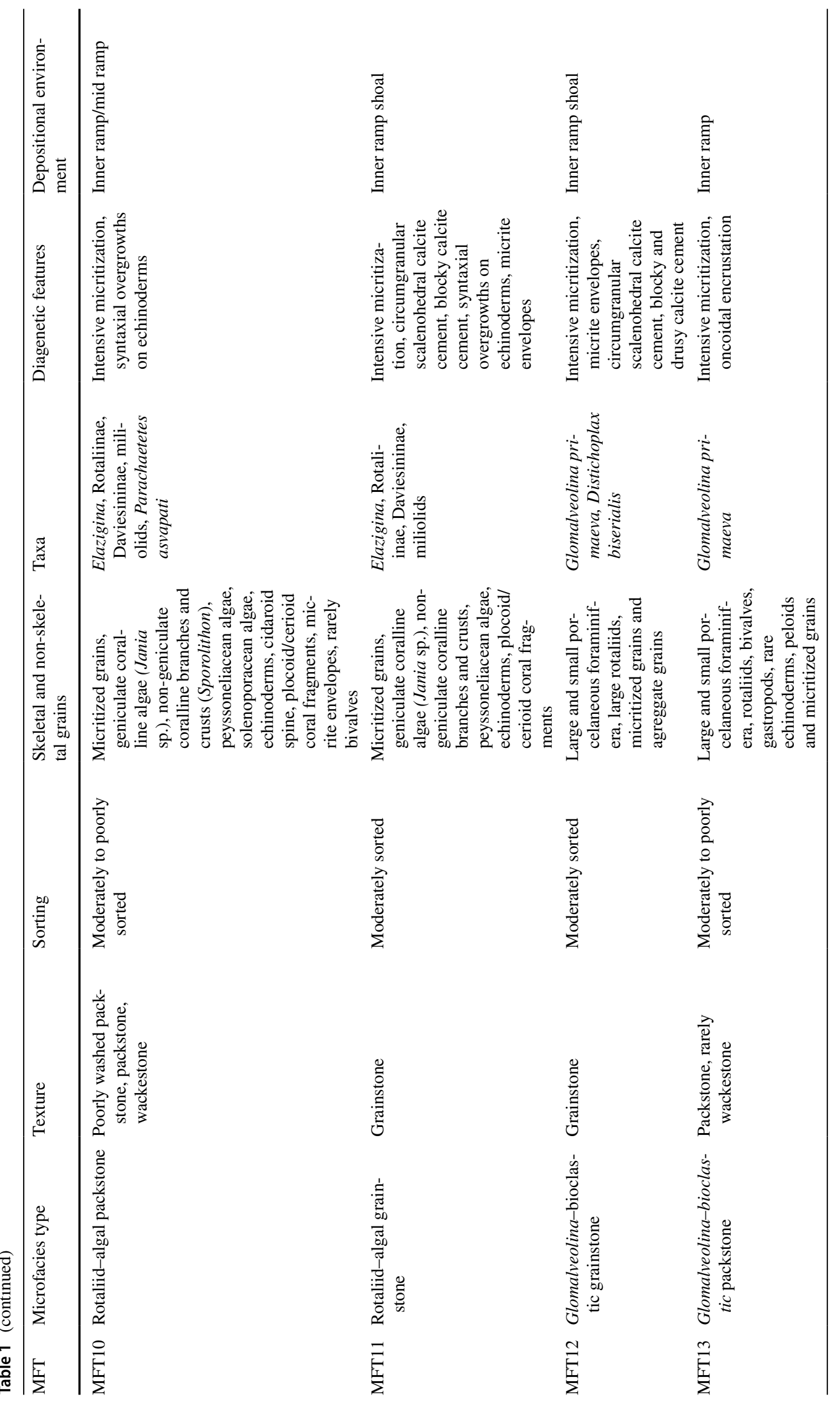



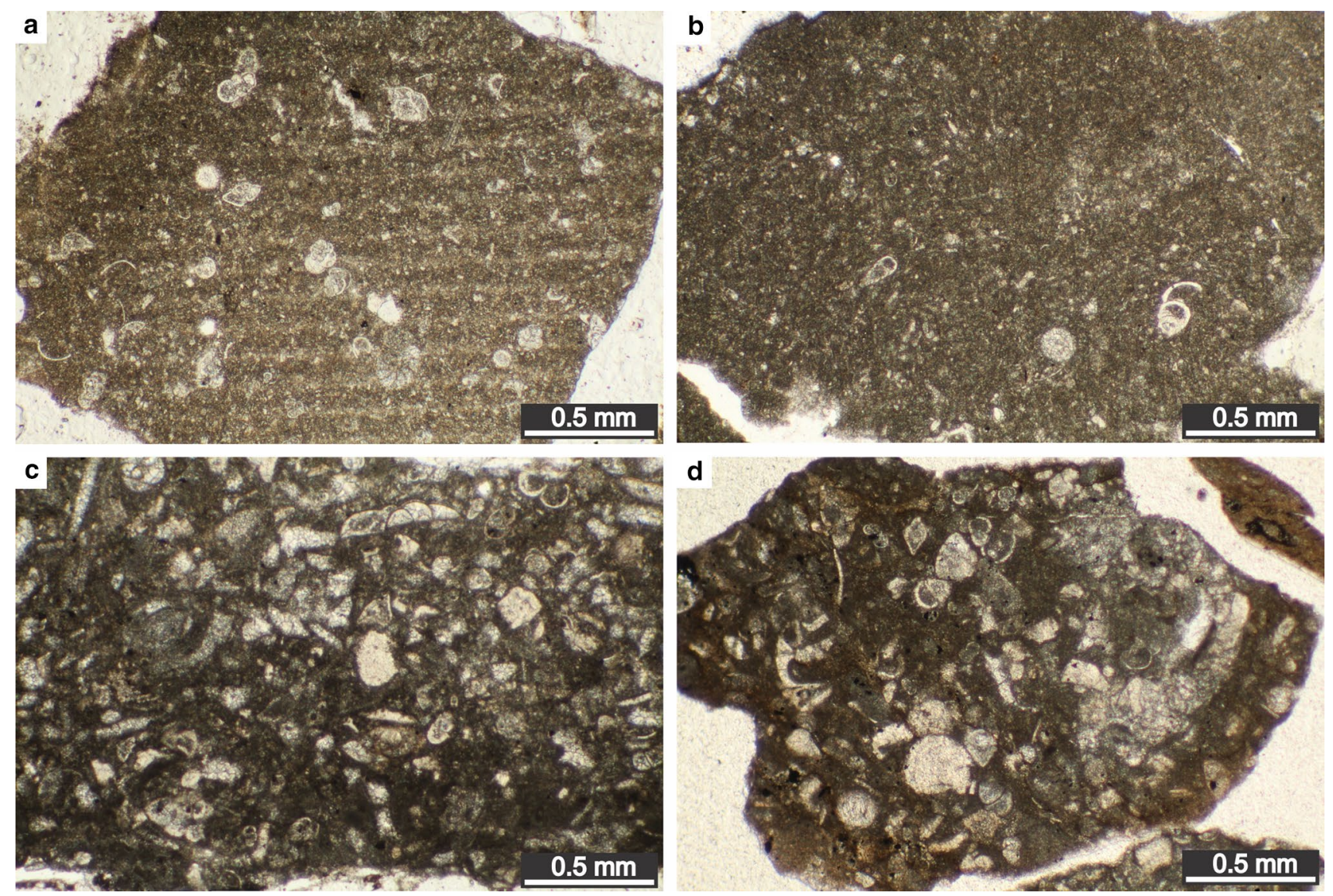

Fig. 9 Photomicrographs of the microfacies MFT 1. a Planktonic foraminiferal wackestone. Sample well 9 (204.2-207.3). b Wackestone with lagenids. Sample well 9 (246.9-250.9). Photomicrographs of the microfacies MFT 2. c Fine-grained foraminiferal-micro-

biodetritic packstone. Sample well 9 (213.4-216.4). d Fine-grained foraminiferal-microbiodetritic packstone. Sample well 2 (91.4100.6). Scale bar $=0.5 \mathrm{~mm}$

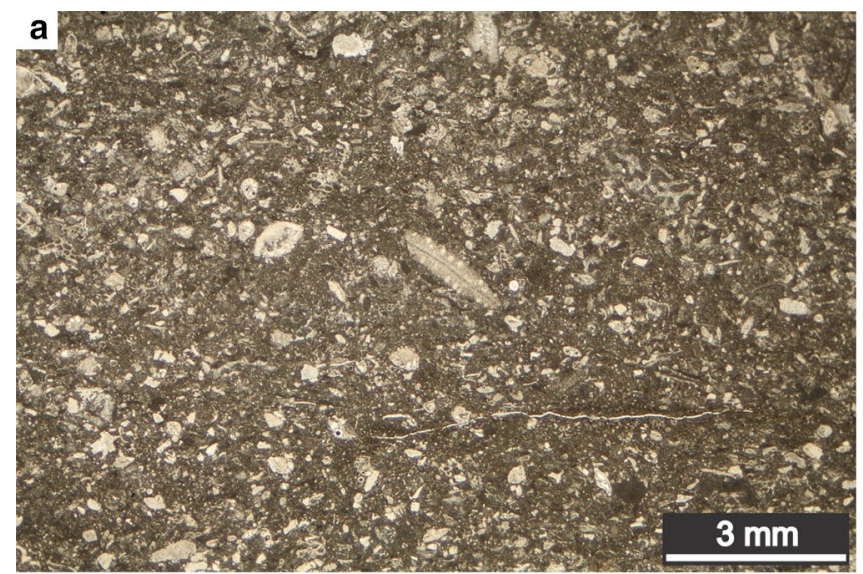

Fig. 10 Photomicrographs of the microfacies MFT 3. a Fine-grained packstone with rotaliids, orthophragminids, echinodermal debris and LBF debris. Sample well 5 (97.7). b Packstone with echinodermal

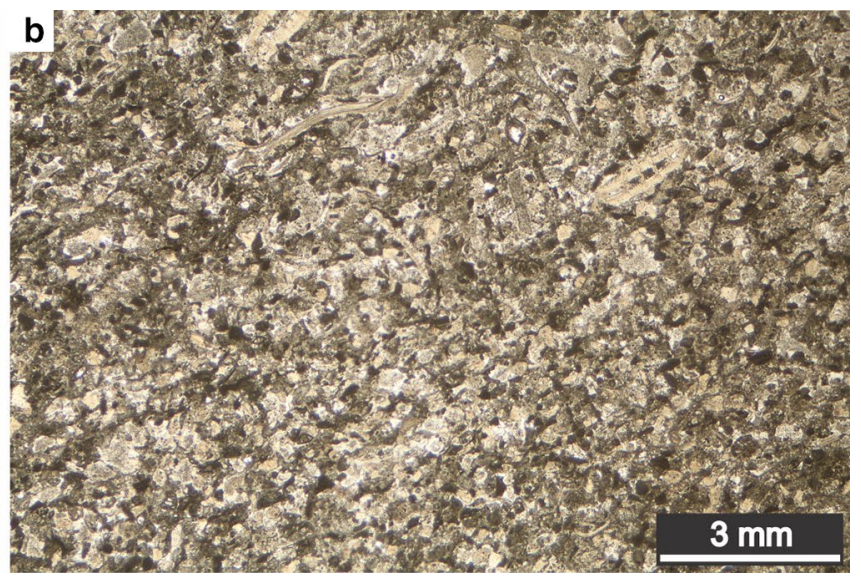

debris, a few Ranikothalia and coralline debris. Sample well 5 (94.6). Scale bar $=3 \mathrm{~mm}$ 
Glomalveolina, large and small porcelaneous taxa and rotaliids. The foraminifera are associated with bivalves and gastropods. Glomalveolina and other bioclasts may act as the nucleus for oncoidal coating (Fig. 17f).

\section{Depositional environment}

Middle Paleocene to Middle Eocene, shallow-marine carbonate platform/ramp systems are characterized by distinct, mainly depth-controlled facies distribution as demonstrated by various investigations (Ghose 1977; Hottinger 1997; Ćosović et al. 2004; Zamagni et al. 2008; Afzal 2010; Bagherpour and Vaziri 2012). Important criteria for the characterization of different facies zones are texture, sorting, diagenetic features, and the environmental distribution of the fossils involved, especially different groups of larger benthic foraminifera. The main drivers of the environmental distribution are the depth of the photic zone, water temperature, nutrient supply, and substrate type (Hottinger
Fig. 12 Photomicrographs of the microfacies MFT 6. a Fine-grained packstone with discoidal orthophragminids, small rotaliids and oyster shell with abundant coralline crusts. Sample well 1 (125.9). b Floatstone with discoidal orthophragminids, algae, rotaliids, oysters and echinodermal debris. Sample well 1 (128.9). c Algal bindstone with intergrowing coralline and peyssoneliacean crusts and fine detritus forming the matrix. Sample well 1 (125.3). d Isolated corallite fragment of a phaceloid/dendroid coral. Sample well 1 (128.9). e Planktonic foraminifera Morozovella sp. (PF). Sample well 1 (130.5). f Peyssoneliacean algae intergrowing with coralline alga Sporolithon sp. (S) and encrusting serpulid. Sample well 1 (133.2). g Intergrowing acervulinid foraminifera and algal crusts are encrusting plocoid/ cerioid coral. Sample well 1 (125). h Intergrowing encrusting cyclostome bryozoan and algal crusts. Sample well 1 (125.3). Scale bars measure $3 \mathrm{~mm}$ for $\mathbf{a}-\mathbf{c}, 1 \mathrm{~mm}$ for $\mathbf{d}$ and $\mathbf{g}, 0.5 \mathrm{~mm}$ for $\mathbf{e}, \mathbf{f}$ and $\mathbf{h}$

1983, 1997; Renema and Troelstra 2001). The variation of the foraminiferal test morphology is a vital depth criterion (Hottinger 1997). Lenticular LBF tend to reduce their axial diameter with depth, i.e. become thinner and more flattened/ discoidal with the progressive depth of the photic zone


Fig. 11 Photomicrographs of the microfacies MFT 4. a Very coarse-grained packstone with coralline branches, orthophragminids, Ranikothalia and echinoderms. Sample well 2 (246.6). b Very coarse-grained packstone with coralline branches, orthophragminids, Ranikothalia and echinoderms. Sample well 5 (100.7). Photomicro-

graphs of the microfacies MFT 5. c Floatstone with abundant echinoderms and some coralline algal debris. Sample well 2 (251.5). d Coarse-grained floatstone with coralline algal debris, echinoderms and a few orthophragminids. Sample well 2 (246.6). Scale bar $=3 \mathrm{~mm}$ 

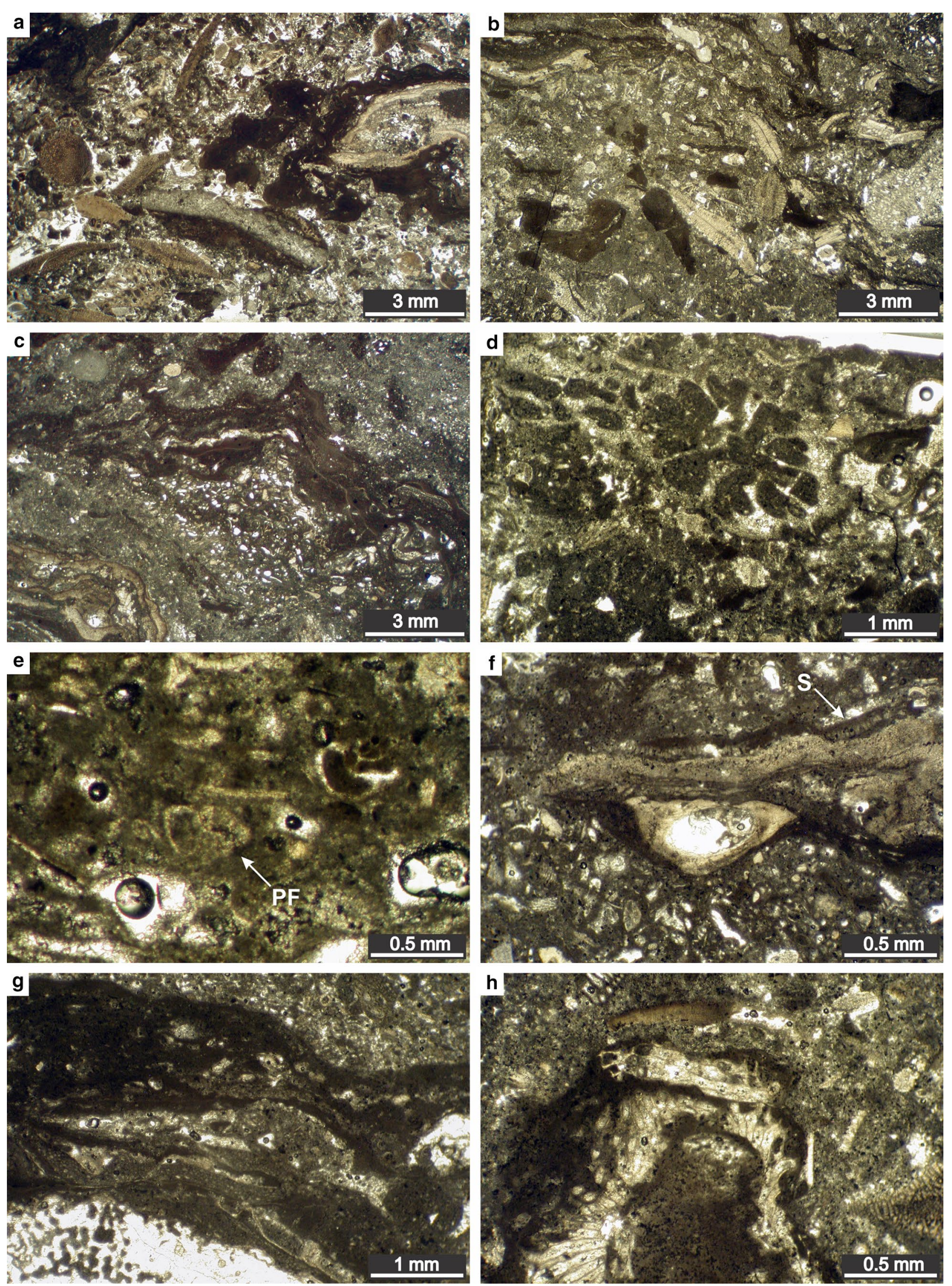

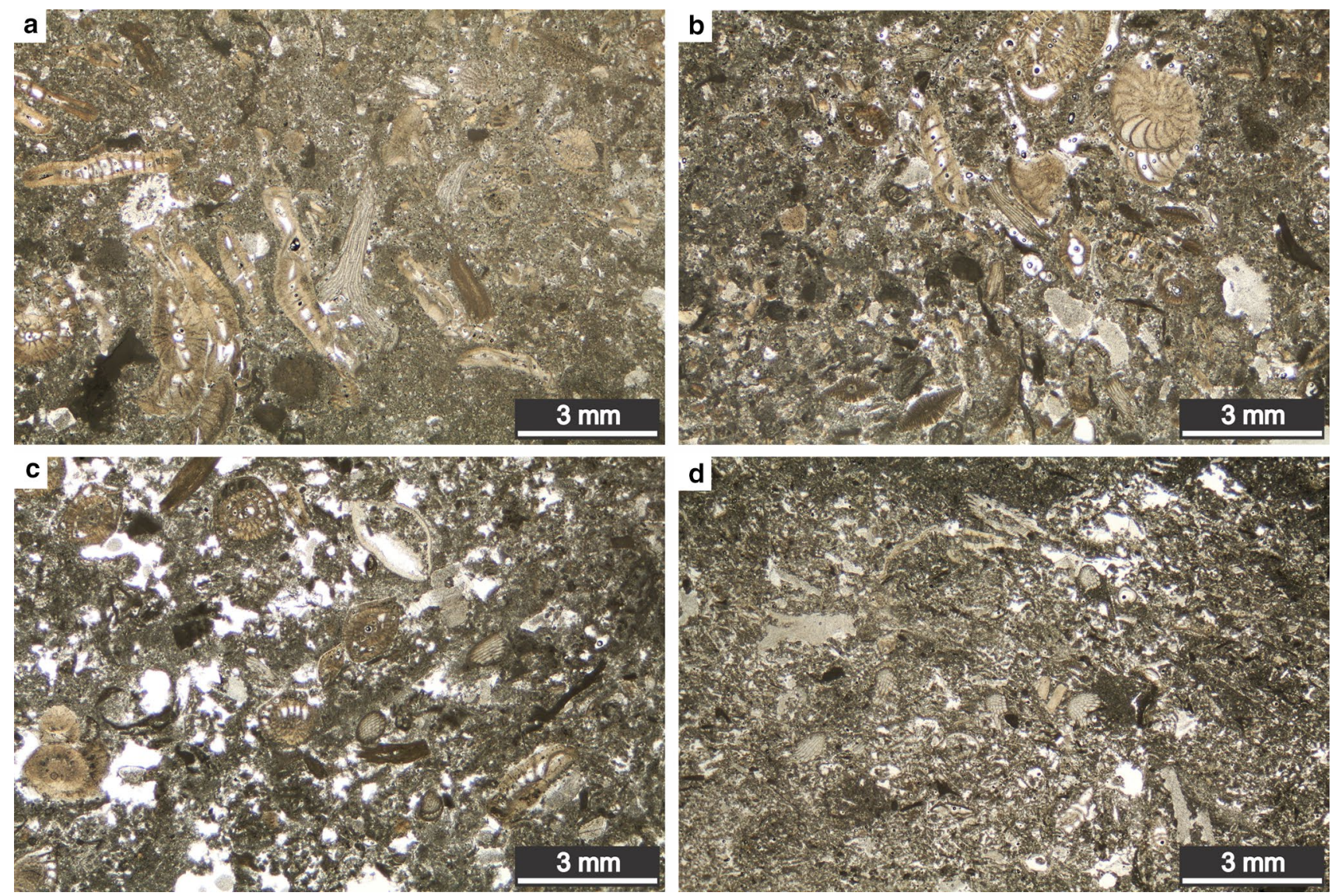

Fig. 13 Photomicrographs of the microfacies MFT 7. a Floatstone with LBF, dendroid cyclostome bryozoans and a few corallines. Sample well 6 (337.4-337.7). b Floatstone with LBF, echinodermal debris and dendroid cyclostome bryozoans. Sample well 6 (347.2-

(Beavington-Penney and Racey 2004; Eder et al. 2018). The reason for this adjustment lies in larger benthic foraminifera hosting algal symbionts, which are dependent on photosynthesis. In the lower photic zone, LBF tend to reduce the wall thickness and increase the relief of the ornamental sculptures to reduce the amount of total light reflection (Hottinger 2006). Flat discoidal foraminifera with thin transparent wall can place their symbionts beneath the test wall (Hohenegger 2009). According to Machaniec et al. (2011), orthophragminids show a particular dependence of the shell morphology on access to light and indirectly on depth, where flat, discoidal tests suggest low energy/low light/increased depth.

In this study, such a trend was observed mainly in the orthophragminids and, to a lesser extent, in Ranikothalia. With the progressive depth of the photic zone, the test morphology of the orthophragminids changes from robust lenticular forms to thin flattened discoidal forms. Robust lenticular forms occur primarily in the coarse-grained MFT 9 (Fig. 15b) and MFT 5 (Fig. 11a, b). The delicate, flattened forms (Fig. 12a, b) occur in more fine-grained textures,

347.5). c Floatstone with miscellaneids and dendroid cyclostome bryozoans. Sample well 6 (348.4-348.7). d Wacke-/floaststone with dendroid cyclostome bryozoans and echinoderms. Sample well 6 (357.8-358.8). Scale bar $=3 \mathrm{~mm}$

especially in the orthophragminid-algal floatstone (MFT 6) of the core 1 (Fig. 6) in well 1. Thick, lenticular orthophragminids indicate a shallower environment, while flattened discoidal ortophragminids point to a deeper environment with low energetic conditions (e.g. Hottinger 1997).

Another critical criterion are coralline algae. Paleogene coralline red algae occur together with corals in the mesooligophotic zone (Pomar et al. 2017). Different coralline genera occur in different environments and water depths, respectively. According to Aguirre et al. (2007), the sporolithaceans dominate the deeper outer platform facies. Solenoporaceans and geniculate corallines are characteristic of the shallow inner shelf shoals. Zamagni et al. (2008) reported the occurrence of thin algal crusts together with flattened discoidal orthophragminids in a deeper mid ramp setting. Towards shallower water, the degree of fragmentation of coralline algae increases, as observed in our material. The orthophragminid-algal floatstone (MFT 6) is characterized by abundant thin algal crusts (Fig. 12c) accompanied by flattened discoidal orthophragminids. In the shallower 
miscellaneid-foraminiferal-algal packstone (MFT 9), the degree of fragmentation is much higher, and coralline algae occur exclusively as fragmented bioclasts (Fig. 15).

Cortoids are important paleoenvironmental indicators. Grainstones with a high percentage of cortoids and other coated grains, together with rounded bioclasts, characteristically form in areas of constant water action, at or above wave base (Flügel 2004). These conditions occur in the 'winnowed platform edge sands' of carbonate platforms as well as in current-washed sand shoals of inner ramp settings (Flügel 2004). Cortoids are especially abundant in MFT 12-13 in the inner ramp. Micrite envelopes developed around grains are also related to more protected seagrassdominated environments (Perry 1999). Some cortoids are the product of destructive micritization by microendolithic organisms. Simultaneously, constructive micrite envelopes related to epilithic organisms have been observed, which eventually led to the formation of aggregate grains by microbial binding. Cortoids have been frequently observed also in MFT 10-11. Rare coated grains within the MFT 4 and MFT 9 of the mid ramp under mesophotic/oligophotic conditions are considered reworked from the inner ramp.

Based on the microfacies and micropaleontological data, a paleoenvironmental model with the distribution of foraminiferal assemblages and algae was reconstructed (Fig. 16). The paleoenvironmental model is mainly based and adapted from Zamagni et al. (2008), Bagherpour and Vaziri (2012), and Afzal (2010) and shows a carbonate ramp with inner ramp, mid ramp and outer ramp setting with different facies belts characterized by differentiated assemblages.

\section{Outer ramp}

The outer ramp is the zone below the storm wave base (SWB). Typical lithologies are argillaceous mudstones and wackestones, frequently associated with marl or shale beds (Flügel 2004). Outer ramp deposits (MFT 1 and MFT 2) were encountered only in well 9 adjacent to the domal structure. The complete absence of shallow-water biota, e.g. LBF or coralline algae, points to deposition below the rhodocline (sensu Liebau 1984), which marks the oligophotic/dysphotic boundary (Pomar et al. 2017). Common planktonic foraminifera and small benthic foraminifera (Midway-type fauna sensu Berggren and Aubert 1975) are characteristic of deep-marine settings. The age relation of the outer ramp deposits with the domal structures is not established in terms of biostratigraphy (e.g. planktonic foraminifera). However, the occasional occurrence of packstones with fine-grained LBF debris (MFT 2) points to a reworking of shallowwater material from adjacent shallow-water environments.
Therefore, the outer ramp deposits could be isochronous with the domal structures.

\section{Mid ramp}

The mid ramp is the zone between the fair-weather wave base (FWWB) and the storm wave base (SMB). Fairweather phases are dominated by suspension fall-out, consisting largely of lime or terrigenous mud, and are commonly bioturbated. Associated grainstone or packstone sediments consist primarily of autochthonous bioclasts (Burchette and Wright 2002).

LBF (orthophragminids, Ranikothalia), coralline and peyssoneliacean algae, small rotaliids, bryozoans, and echinodermal debris are the most common organisms of the mid ramp depositional setting (Zamagni et al. 2008). These organisms were prolific carbonate producers in the mesophotic-oligophotic depths (Pomar et al. 2017). LBF, red algae and echinoderms are occurring in packstones/floatstones/rudstones. Apart from differences in their quantitative distribution, the studied successions exhibit different grain sizes reflecting different water-energy conditions, i.e. shallowing (shift to coarser grain size) or deepening (shift to more fine grain size). This simple trend becomes overprinted by resedimentation of coarse-grained material into deeper water (Fig. 11a, b).

MFT 3 is a fine-grained packstone deposited in a lowenergetic deeper mid ramp. Rare thin coralline crusts (mainly Sporolithon sp.) suggest deposition under oligophotic conditions above rhodocline (Pomar et al. 2017). The presence of few planktonic foraminifera points to a deeper mid ramp.

Coarse-grained bioclasts consisting of coralline algae, LBF and echinoderms (MFT 4-5) are transported into the deeper parts of the ramp, intercalated between predominately fine-grained limestones. Occasionally, bioclastic material originating from the shallower inner ramp was redeposited into the mid ramp. Dasycladalean green alga, Neomeris aff. avellanensis, has been interpreted as allochthonous, i.e. being transported from the inner ramp. Glomalveolina found in the MFT5 is interpreted as allochthonous, i.e. being transported from the inner ramp (MFT 12-13).

LBF biodiversity in MFT 6 is limited chiefly to flattened orthophragminids. This group of flattened foraminifera generally occupies the deepest-water environment among the larger foraminifera, down to the lower limit of the photic zone (Zamagni et al. 2008; Beavington-Penney and Racey 2004). Abundant coralline and peyssoneliacean algal crusts often form bindstones, which give evidence of the lateral or ramp-upward occurrence of bionconstructions. Genus Sporolithon points to deeper conditions (Aguirre et al. 2007). The deeper environment is also documented by a few 


4Fig. 14 Photomicrographs of the microfacies MFT 8. a Dense micrite (D-m) and agglutinated microfabric (Agg.). At the top and bottom of the picture are encrusting plocoid/cerioid corals (C). Sample well 6 (340.5-340.8). b Agglutinated/peloidal microfabric with embedded corals. Sample well 6 (334.4-334.7). c Peloidal/clotted microfabric. Sample well 6 (329.8-330.1). d Detail of photomicrograph c. Peloidal/clotted microfabric is encrusted by thin coralline and acervulinid crusts. Sample well 6 (356-356.3). e Plocoid arrangement of Actinacis-type corallites. Sample well 6 (329.8-330.1). f Phaceloid/dendroid Oculina-type corallite in the centre. Sample well 6 (356-356.3). Scale bars measure $3 \mathrm{~mm}$ for $\mathbf{a}-\mathbf{c}, 1 \mathrm{~mm}$ for $\mathbf{d}-\mathbf{f}$

planktonic foraminifera (Fig. 12e) occurring in the very finegrained textures.

MFT 7 is a floatstone associated with MFT 8 and MFT 9. Zamagni et al. (2009) described similar microfacies with bryozoans, algae and bioclastic debris as lateral skeletal deposits associated with microbialite-coral mounds. Baceta et al. (2005) documented comparable microfacies as interreef and fore-reef facies.

Microbialite-coral boundstone (MFT 8) was described by Zamagni et al. (2009) on a late Paleocene carbonate ramp from SW Slovenia as microbialite-coral mounds associated with lateral skeletal deposits and abruptly overlain by stratified foraminiferal-algal packstones. In Sirt Basin, Bebout and Pendexter (1975) described coral-algal micrite as "a loose framework of branching and laminated corals with a micrite matrix". Bebout and Pendexter (1975) most likely recognized the micrite matrix as a depositional matrix with embedded corals and not as microbial in origin. Zamagni et al. (2009) pointed out that the micrite matrix is most likely of microbial origin. The microbialite-coral boundstone alternates with MFT7 and MFT 9 in a low-energetic mid ramp under mesophotic conditions. Most of the micrite was microbially trapped. According to Zamagni et al. (2009), early lithification of the microbial crusts provided a hard surface for encrusting corals to grow on it.

MFT 9 is dominated by miscellaneids, Ranikothalia, and larger rotaliids. Such foraminiferal assemblages were also described from other Tethyan Paleocene localities, e.g. Galala Mountains in Egypt (Scheibner et al. 2003), Taleh Zang Formation in the Zagros Mountains (Bagherpour and Vaziri 2012) and Indus Basin in Pakistan (Afzal 2010). According to Ghoose (1977), miscellaneids occur mainly in the near-reef zone of the back reef. Miscellaneids have been described from inner ramp together with porcelaneous taxa (Zamagni et al. 2008). They have also been recovered from deeper carbonate settings associated with coral-algal patch reefs under mesophotic conditions (Consorti and Köroğlu 2019). Rare Glomalveolina is considered allochthonous, i.e. displaced from proximal environments.

\section{Inner ramp}

The inner ramp comprises the euphotic zone sensu Pomar (2001) between the upper shoreface and the fair-weather wave base (Flügel 2004). The inner ramp consists of bioclastic sand shoals which form sheet-like grainstones. Lagoonal sediments range from mud-, wacke- to packstone with restricted biota (Burchette and Wright 1992).

MFT 10 is a packstone with occasionally poorly washed texture and was deposited in a protected back-shoal environment. MFT 11 is a rotaliid algal grainstone with common rotaliids, geniculate coralline algae and solenoporacean algae, and points to deposition on an inner ramp shoal environment. Geniculate corallines and solenoporaceans have been reported from the lower euphotic depth (Pomar et al. 2017). Both algal types are common constituents of backreef sands (Baceta et al. 2005). Coralline algal grainstone with geniculate corallines has been described from the high energetic inner platform (Aguirre et al. 2007; Scheibner et al. 2007) and lagoon behind an inner ramp shoal (Bagherpour and Vaziri 2012).

MFT 12 and MFT 13 represent the shallowest facies belt preserved on the top of the Intisar domal structure (Fig. 5). Both MFT's mark a significant shift in the foraminiferal assemblages from predominately hyaline tests of the mesophotic-oligophotic mid ramp to predominately porcelaneous taxa (Fig. 17) of the euphotic inner ramp. Porcellaneous foraminifers inhabit shallow-water, protected environments, but they also occur reworked in sand shoals (Španiček et al. 2017; Benedetti 2018). MFT 12 (Fig. 17a-c) represents the highest energetic environment. Very shallow conditions are evident by abundant micritization of the bioclasts, oncoid coatings and aggregate grains (Fig. 17a). MFT 13 (Fig. 17d-h) was deposited in a protected low-energy lagoonal/back-shoal environment behind a grainstone shoal barrier. Mresah (1993) described MFT12 and MFT 13 as "alveolinid wackestone-packstone" in a narrow facies belt in the "barrier reef" area sensu Gumati (1992) (Fig. 2).

\section{Discussion}

\section{Depositional geometry}

The depositional geometry of the Upper Sabil shallowmarine carbonates is controversially discussed. The Intisar domal structures of the Intisar embayment are widely accepted as pinnacle reefs/bioherms surrounded by deepmarine deposits (Terry and Williams 1969; Brady et al. 1980; Gumati 1992). The main issue concerning this interpretation is that the entire domal structure is generally regarded as a giant buildup. For example, the coral member 

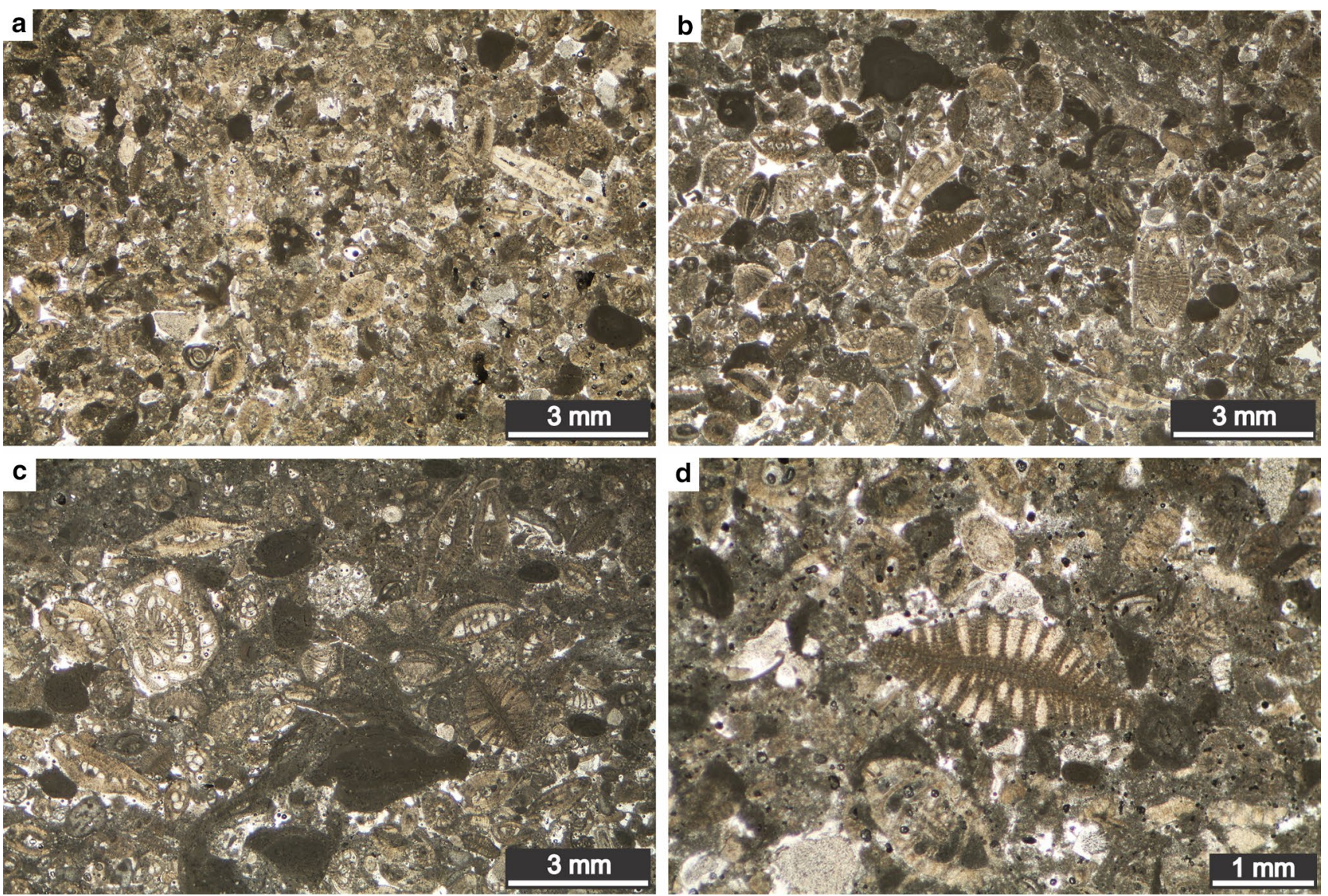

Fig. 15 Photomicrographs of the microfacies MFT 9. a Densely packed foraminiferal packstone with miscellaneids and some Ranikothalia, orthophragminids, rotaliids, coralline algal branches and echinodermal debris. Sample well 6 (354.5-354.8). b Densely packed foraminiferal packstone with Ranikothalia, miscellaneids, orthophragminids and coralline algal branches. Sample well 6 (354.2354.5). c Densely packed foraminiferal packstone with abundant

sensu Terry and Williams (1969), developed when "the coral biomicrite patches coalesced into one massive coral reef body". This interpretation gives the impression that the coral reef body represents a frame reef sensu Riding (2002) with skeletons in contact. Moreover, a rimmed carbonate platform with a barrier reef and a steep slope surrounding the Intisar embayment was interpreted (Gumati 1992; Spring and Hansen 1998), a frame reef sensu Riding (2002) with significant topographic relief. Recent scleractinian corals form wave-resistant barrier reefs in the euphotic zone (e.g. Great Barrier Reef). Corals also colonize the mesophotic zone (water depth exceeding $40 \mathrm{~m}$ ), as recently demonstrated in the Adriatic Sea by Corriero et al. (2019). Pomar et al. (2017) stated pre-late Tortonian corals could neither form large, wave-resistant structures in the euphotic shallow-marine areas nor rims up to sea level. Paleogene corals thrived mainly in the mesophotic to oligophotic conditions
Ranikothalia and some miscellaneids, orthophragminids and corallines. Sample well 6 (341.7-342). d Densely packed foraminiferalalgal packstone with miscellaneids, orthophragminids, rotaliids and echinodermal debris. Orthophragminids are characterized by thick lenticular test morphology. Sample well 6 (359.1-359.7). Scale bars measure $3 \mathrm{~mm}$ for $\mathbf{a}-\mathbf{c}, 1 \mathrm{~mm}$ for $\mathbf{d}$

along the whole ramp profile (Pomar et al. 2017). In the mid ramp, large coral colonies occur stacked in small mounds with a "cluster" internal structure (sensu Riding 2002). However, there are several examples on Paleogene corals (Bosellini and Russo 1992; Vescogni et al. 2016; Bosellini et al. 2020), where the authors interpreted the corals building wave-resistant reefs within the euphotic zone associated with larger porcelaneous taxa, e.g. alveolinids from Monte Postale (Vescogni et al. 2016). Contrasting models have been presented; often the same localities and outcrops were revisited and revised by particular authors.

Red algae are generally considered mesophotic biota (Pomar et al. 2017). Corals are important carbonate producers in the mesophotic zone (Pomar et al. 2017), but have also been reported from shallow euphotic zone (Vescogni et al. 2016). Larger porcelaneous foraminifera are common epiphytes in the grass meadows in the shallowest euphotic 

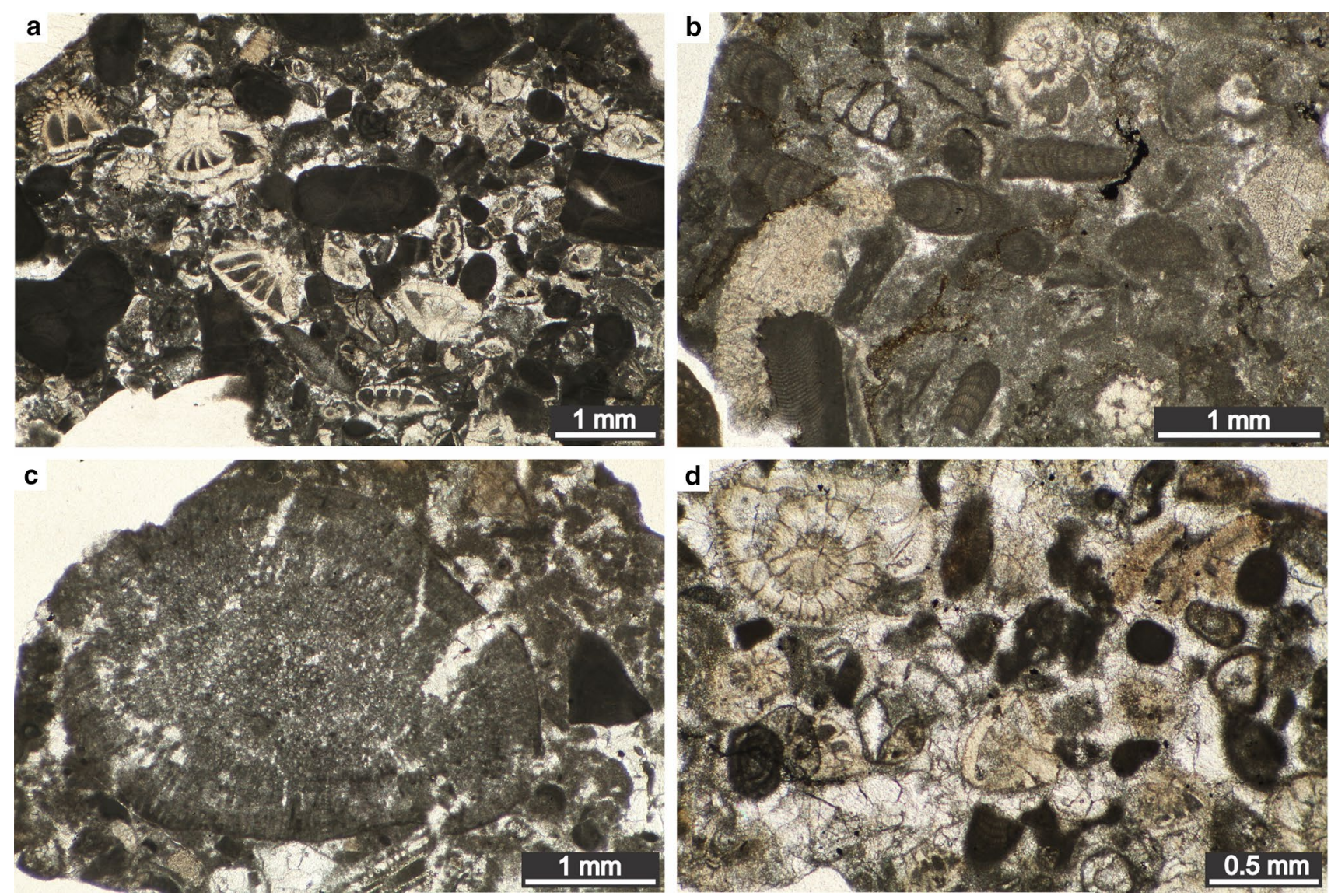

Fig. 16 Photomicrographs of the microfacies MFT 10. a Densely packed packstone with abundant rotaliids, Elazigina sp. and coralline branches. Sample well 8 (3-6.1). b Packstone with branches of geniculate alga Jania sp. and a rotaliid. Sample well 8 (15.2-24.4).

zone (Benedetti 2018). Perforated-lamellar larger foraminifera, e.g. rotaliids and miscellaneids, inhabited the shallow euphotic zone (Zamagni et al. 2008) and the mesophotic zone (Consorti and Köroğlu 2019). Nummulitids, e.g. orthophragminids, are dominant LBF in the mesophotic/oligophotic zone (Pomar et al. 2017).

The current study has demonstrated that the described 13 MFT can be included into a carbonate ramp model (Fig. 18). A cross section (2D geometry) between Intisar domal structure 1 and domal structure 2 is reconstructed by means of well correlation (Fig. 19) with MFT distribution. The well map is shown in Fig. 1c. The distal well 9 penetrated only outer ramp deposits (MFT 1-2). Towards the rim well 5, the grain size increases. MFT 3 is the dominant microfacies with intercalations of coarse-grained MFT 4-5. The lower part of the centre well 6 and off-centre well 8 is characterized by MFT 10-11. The middle part consists mainly of MFT 4-5. The upper part consists of MFT 7-9 with scattered microbialite-coral boundstone (MFT 8). MFT 12-13 preserved on the crest of the domal structure are common microfacies types found on a Paleocene Tethyan inner ramp

c Solenoporacean alga Parachaetetes asvapati Rao and Pia. Sample well 8 (33.5-42.7). Photomicrographs of the microfacies MFT 11 d Grainstone with rotaliids and geniculate coralline algae. Sample well 8 (3-6.1). Scale bars measure $1 \mathrm{~mm}$ for $\mathbf{a}-\mathbf{c}, 0.5 \mathrm{~mm}$ for $\mathbf{d}$

of the shallow euphotic zone (e.g. Bagherpour and Vaziri 2012) and are widespread in the Sirt Basin. Mresah (1993) described MFT 12-13 under the name alveolinid wackestone-packstone (see Fig. 4g in Mresah 1993) as a narrow facies belt occurring in the high-energetic shoal environment on a carbonate ramp. On the contrary, Gumati (1992) described it as a platform carbonate facies in a back-reef/ lagoonal setting behind a barrier reef (see Fig. 9c in Gumati 1992). MFT 12-13 have been found in several areas of Intisar embayment, including the Intisar domal structures, but interpreted differently by each author.

The MFT of the Intisar domal structures are practically identical to the MFT of the carbonate ramp deposits described by Mresah (1993) or "barrier reef" sensu Gumati (1992). Therefore, the pinnacle reefs (Terry and Williams 1969; Brady et al. 1980) and the barrier reef surrounding the Intisar embayment (Gumati 1992) are re-interpreted as carbonate ramp deposits. The Intisar domal structures are in fact erosional relics of a carbonate ramp and are supposedly part of the carbonate ramp deposits described by Mresah (1993). 

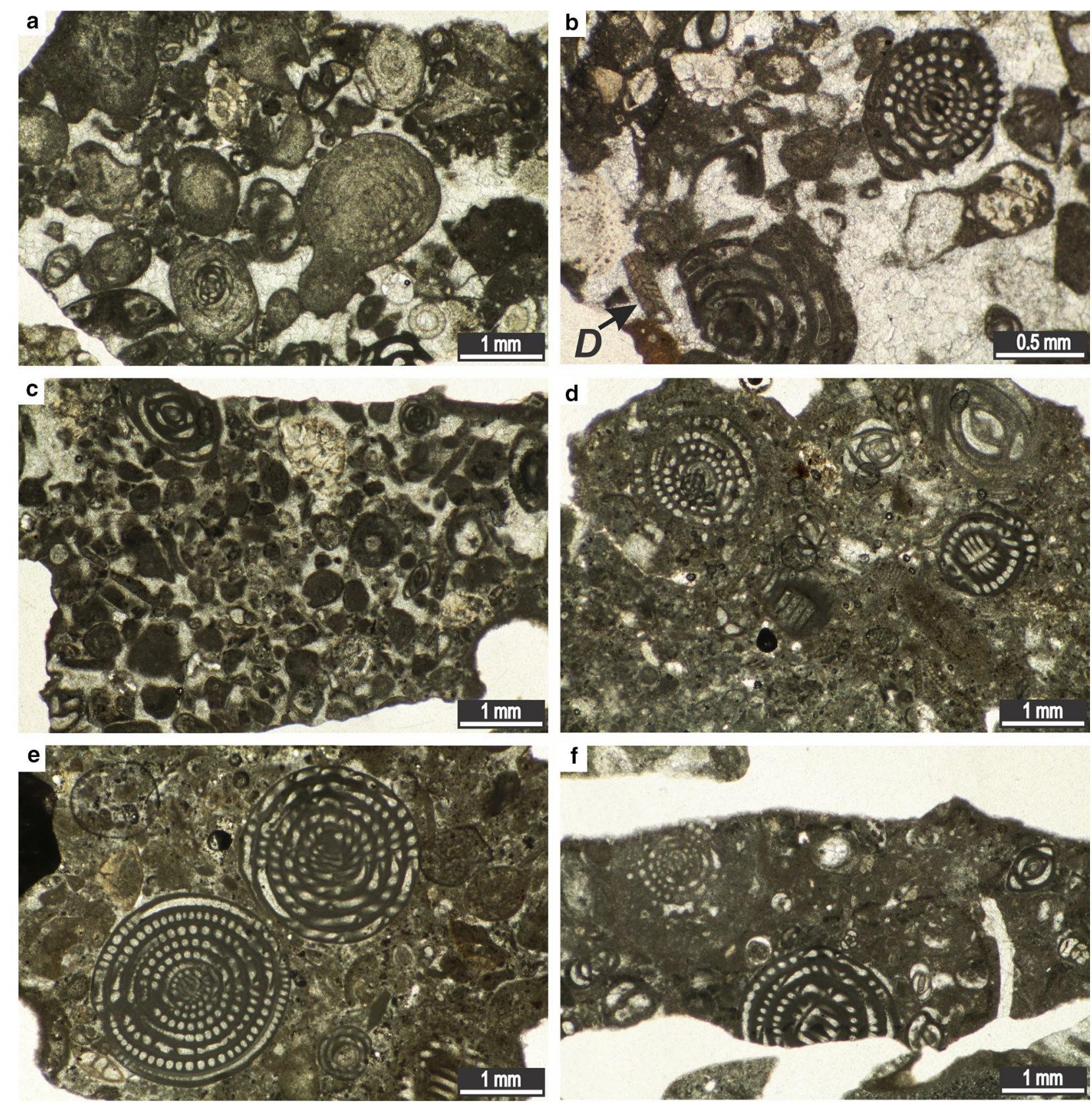

fixise

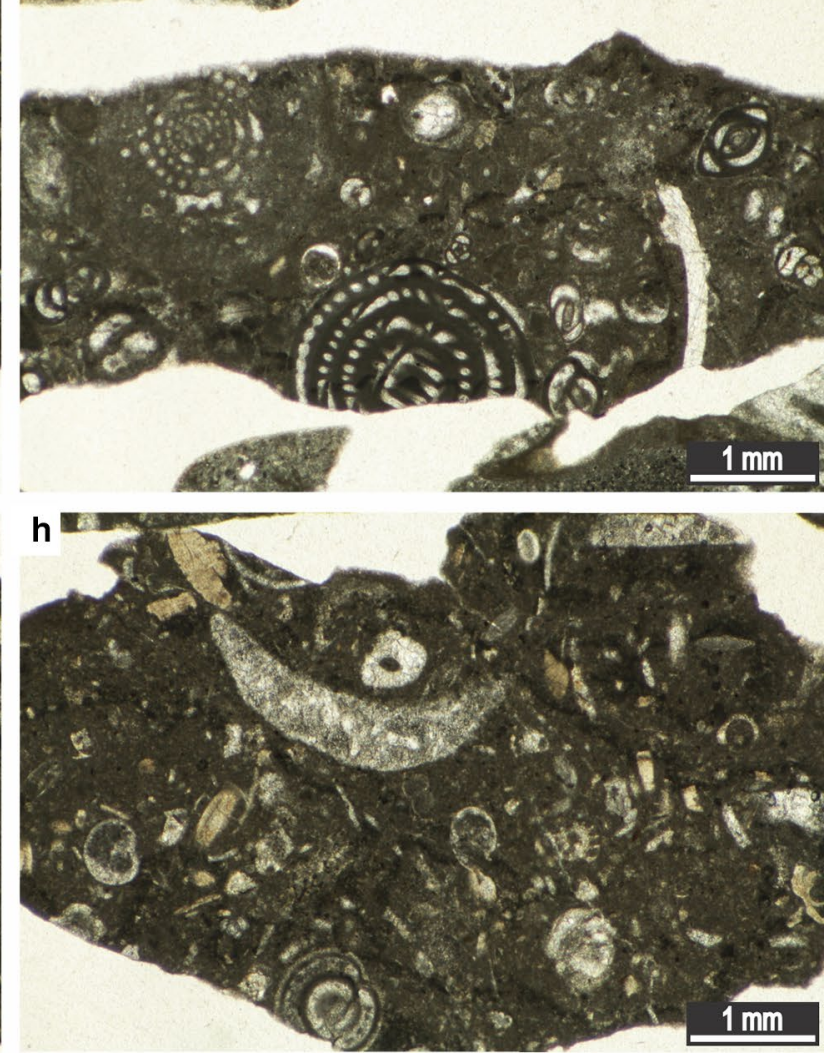


4Fig. 17 Photomicrographs of the microfacies MFT 12. a Grainstone with Glomalveolina, small rotaliids and miliolids. Grains are micritized. Micritized Glomalveolina in the centre forms an aggregate grain. A miliolid exhibits a microbial coating. Sample well 7 (368.8378). b Grainstone with Glomalveolina, small rotaliids, miliolids and coralline alga Distichoplax biserialis Dietrich (marked with $D$ ). Sample well 7 (368.8-378). c Grainstone with miliolids, rotaliids, other small benthic foraminifera and micritic clasts. Sample well 7 (368.8378). Photomicrographs of the microfacies MFT 13. d Very-finegrained packstone with Glomalveolina, miliolids and fine-grained detritus. Sample well 7 (368.8-378). e Packstone with Glomalveolina and some miliolids, rotaliids and micritic clasts. Sample well 7 (323.1-332.2). f Glomalveolina-miliolid packstone. Glomalveolina on the left side forms a nucleus of the oncoid. Sample well 7 (368.8378). g Glomalveolina wackestone with microbial encrusted phaceloid/dendroid corallite. Sample well 7 (323.1-332.2). h Packstone with bivalves, gastropods and miliolids. Sample well 7 (368.8-378). Scale bars measure $1 \mathrm{~mm}$ for $\mathbf{a}$ and $\mathbf{c}-\mathbf{h}, 0.5 \mathrm{~mm}$ for $\mathbf{b}$

\section{Onset and demise of the Upper Sabil carbonate factory}

The eastern sector of the Sirt Basin is characterized by two Paleocene shallow-marine carbonate cycles (Lower and Upper Sabil) sandwiched between deep-marine deposits (Mresah 1993). During the Danian stage, a vast shallowmarine Lower Sabil carbonate domain was established (Hallet and Clark-Lowes 2016). Mresah (1993) suggested a relative sea-level fall at the end of the Lower Sabil cycle due to the presence of evaporites, which extend laterally to the platform margin.

The term deep-marine deposits refers to the fine-grained sediments underlying and overlying the Upper Sabil Formation, Sheterat and Harash/Kheir Formations, respectively. The exact biostratigraphic dating and detailed microfacies of these formations are beyond the scope of this study; therefore, only a brief lithological description of these units is provided to understand the evolution of the Upper Sabil Formation, and the onset and demise of the carbonate factory. The Sheterat Formation (Fig. 3) is composed of soft, fissile shale, shaly micritic limestone, and chalk (Hallett and Clark-Lowes 2016). According to Barr and Weegar (1972), the Sheterat Formation conformably overlies the Lower Sabil carbonates. Bezan (1996) reports Sheterat Formation as a drowning event. Due to the rapid recovery of the Upper Sabil carbonate factory, Sheterat Formation is considered as a short-lived flooding event instead, where the maximum flooding surface is placed. Upper Sabil Formation and Sheterat Formation are both together regarded as one sequence. Sheterat Formation is part of the TST cycle, while the Upper Sabil Formation represents the HST (Fig. 19a).

The carbonate ramp deposits of the Upper Sabil Formation rapidly prograded over the deep-marine deposits. The mid ramp deposits are overlain by the inner ramp deposits of the euphotic zone. The Upper Sabil carbonate ramp was again subjected to subaerial exposure due to a major sea-level fall, which caused an influx of meteoric waters. According to Mresah (1993), this event resulted in the generation of porosity in these ramp deposits through meteoric leaching of carbonates. Bebout and Pendexter (1975) attributed the excellent porosity in the Zelten field to leaching by groundwater. Subaerial exposures of carbonate depositional systems produce subaerial unconformities, often of regional extent. According to Flügel (2004), subaerial exposure and meteoric diagenesis are important processes in developing and preserving porosity. Reservoirs associated with unconformities have been estimated to contain 20-30\% of known recoverable hydrocarbons (Halbouty et al. 1970; as cited in Flügel 2004). Mresah (1993) suggests that the excellent porosity present in the Upper Sabil carbonates is related to diagenetic processes associated with the subaerial exposure and, therefore, the hydrocarbon reservoirs hosted in these carbonates are related to the subaerial exposure. Iron oxide crusts and dog-tooth cement precipitated within interparticle pore space indicate a meteoric diagenetic environment (Fig. 20). Penetrative staining of strata underlying discontinuity surfaces by iron oxides can indicate oxidation due to pedogenesis and karstification (Flügel 2004).

There are several reasons for drowning events of shallowmarine carbonates. One among them is large sea-level changes caused by tectonic plus eustatic events (Schlager 1981, 2010).

Spring and Hansen (1998) demonstrated that the Harash Formation infills the irregular surface of the Upper Sabil paleotopography. Harash Formation gradually onlaps the domal structures (Fig. 19a). The deposition of the Kheir Formation is considered a major transgression that led to the final drowning of the Upper Sabil Formation (Gumati 1992). In the upper part of the former, Lockhartia cf. diversa was found (Fig. 21). According to Hottinger (2014), Lockhartia diversa is constrained from SBZ5 to lower SBZ7. Therefore, the upper part of the Kheir Formation is already Ilerdian (Early Ypresian) in age. The Upper Sabil Formation is Selandian-Early Thanetian in age, i.e. there is a significant sedimentary gap of at least whole Late Thanetian (SBZ 4) on the crest of the domal structure. Paleocene-Eocene thermal maximum (PETM) is characterized by a eustatic sea-level rise (Sluijs et al. 2008), which eventually led to the drowning of the previously exposed domal structures.

\section{Conclusions}

Based on the results, the following conclusions can be drawn:

A. 13 microfacies types (MFT) were defined, representing different environments on a carbonate ramp. MFT 12-13 


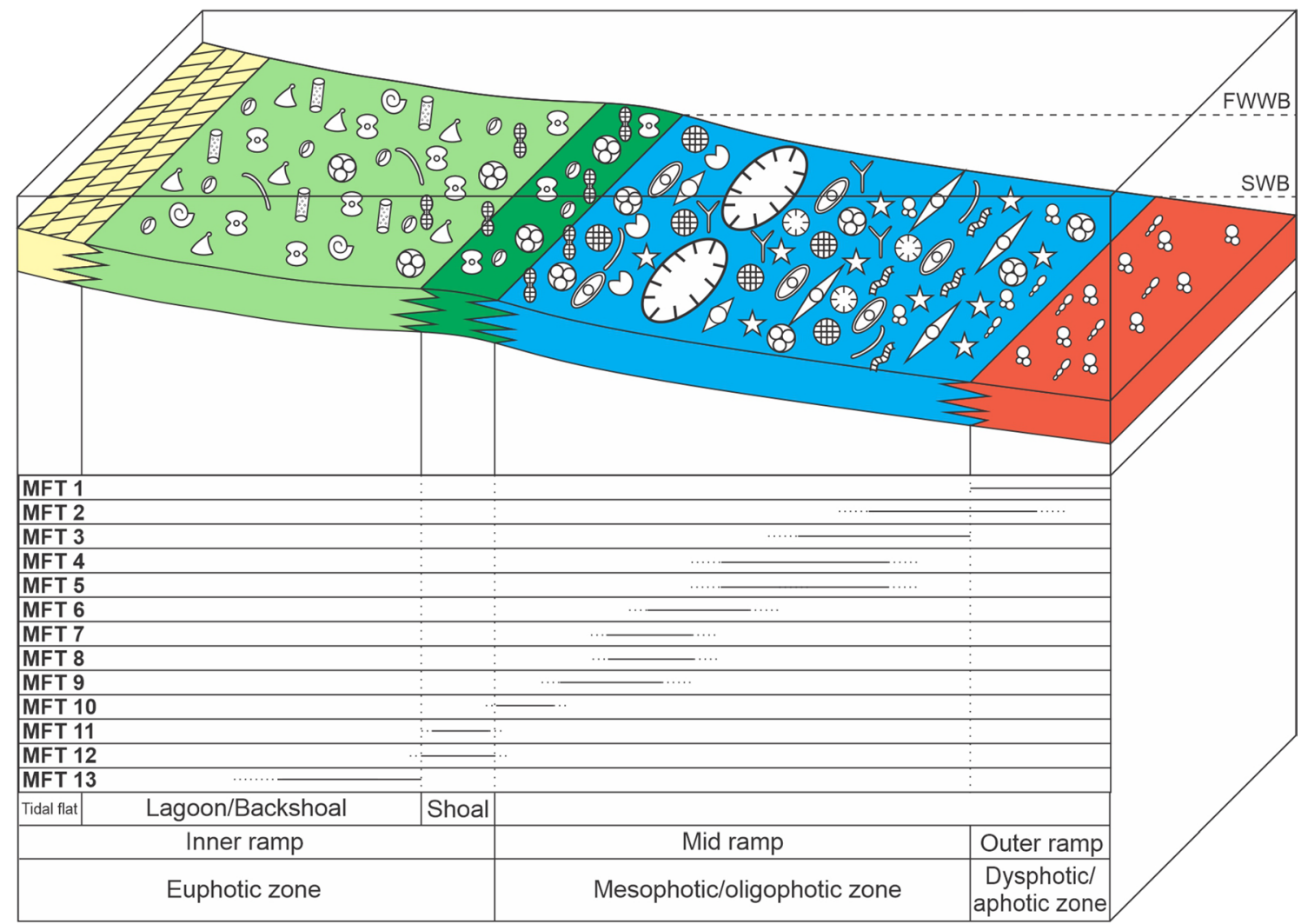

\section{LEGEND}

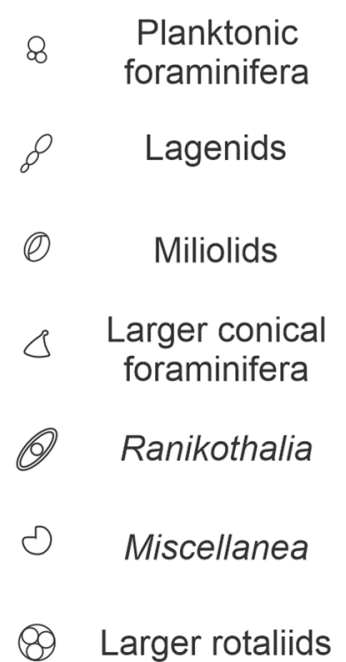

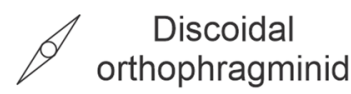

Lenticular orthophragminid
曲
Fragmented coralline branches
๑ Geniculate coralline algae

\section{Coralline crusts}

Ey Microbialite-

$\otimes \quad \begin{gathered}\text { Coral } \\ \text { fragments }\end{gathered}$

¿ Echinoderms

Bryozoans

Bivalve

Gastropod

Fig. 18 Middle to Late Paleocene paleoenvironmental model with respect to the distribution of different shallow-marine organisms (adapted and modified from Zamagni et al. 2008 and Bagherpour and Vaziri 2012)

represent the euphotic inner ramp preserved on the crest of the domal structure.

B. The general sedimentary evolution of the Intisar domal structures previously interpreted as pinnacle reefs/bioherms (Terry and Williams 1969; Brady et al. 1980; Gumati 1992) correspond to the Tethyan
Middle to Late Paleocene carbonate ramp models (e.g. Zamagni et al. 2008; Afzal 2010; Di Carlo et al. 2010; Bagherpour and Vaziri 2012). The majority of the MFT are allochthonous carbonates. Only a minor proportion of MFT are true autochthonous carbonates (boundstone). 


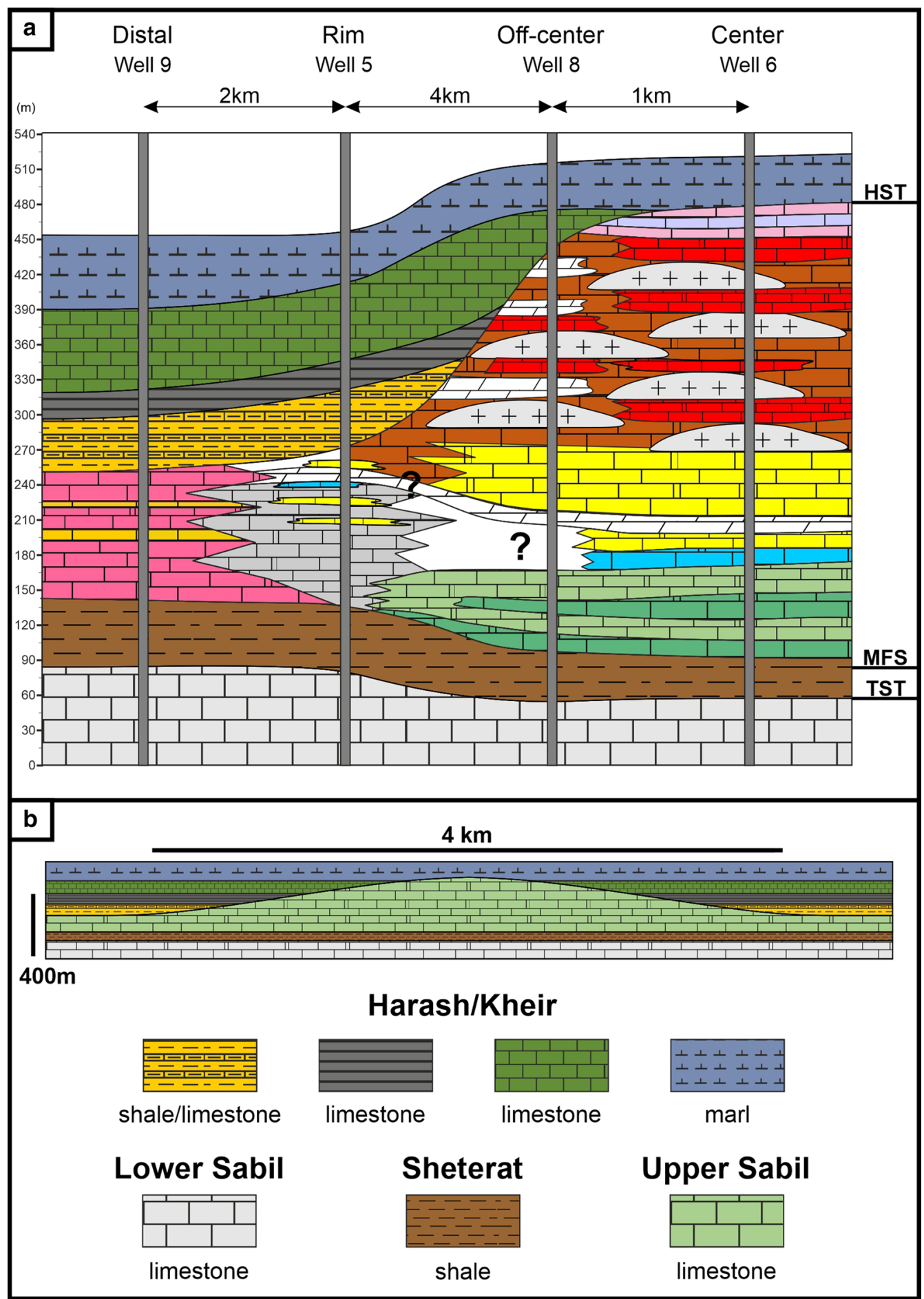

Fig. 19 a A representative cross-section (2D geometry) of a domal structure with MFT distribution is based on well correlation. For MFT legend, see Figs. 4, 5, and 6. The question mark indicates areas of high uncertainty due to insufficient data. The vertical scale

C. The Intisar domal structures represent erosional relics of carbonate ramp deposits with precisely the same MFT as the so-called »reef and platform facies« of Gumati is highly exaggerated. On the right side, systems tracts are indicated. b A cross section of a domal structure with height proportional to length

(1992) located at the margin of the "Intisar embayment" or carbonate ramp deposits sensu Mresah (1993).

D. The Harash and Kheir Formations overlying the Upper Sabil shallow-marine carbonates need exact biostrati- 

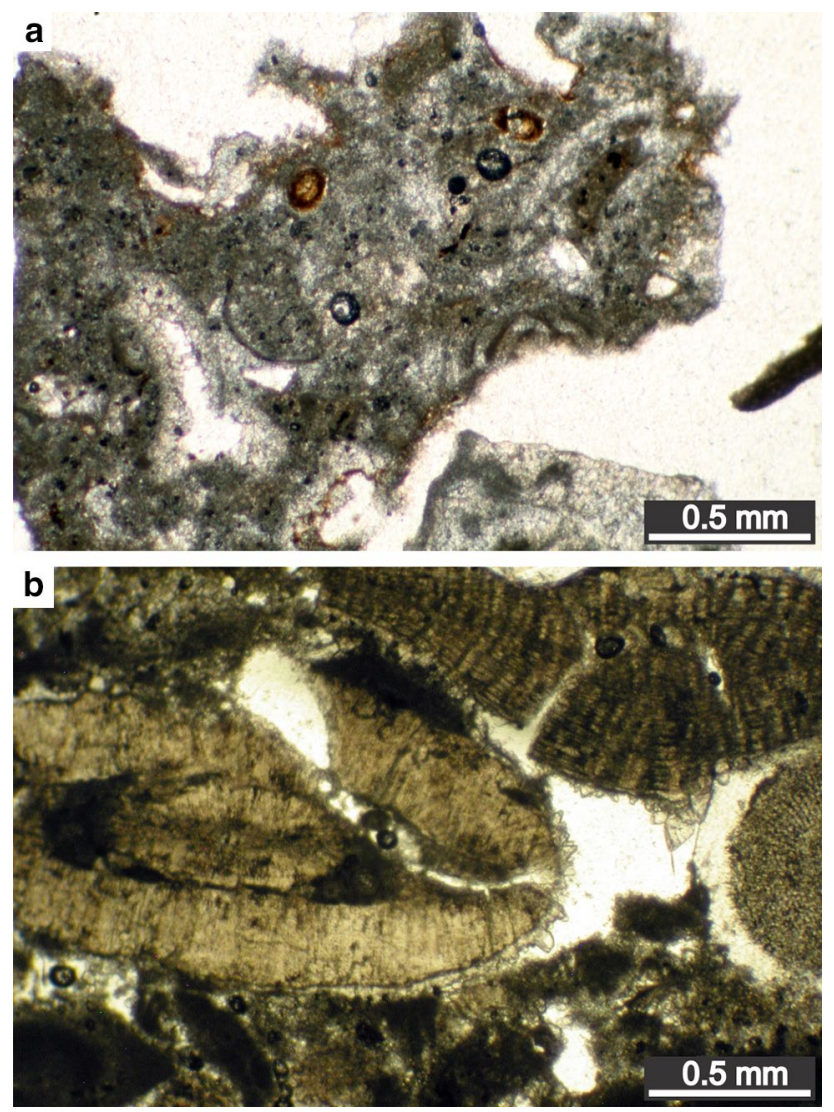

Fig. 20 Top of the Upper Sabil Formation. a Iron oxide (red) rimming pore space. Sample well 6 (396.2-405.4). b Grain-rimming dog tooth cement. Sample well 2 (246.6). Scale bar $=0.5 \mathrm{~mm}$
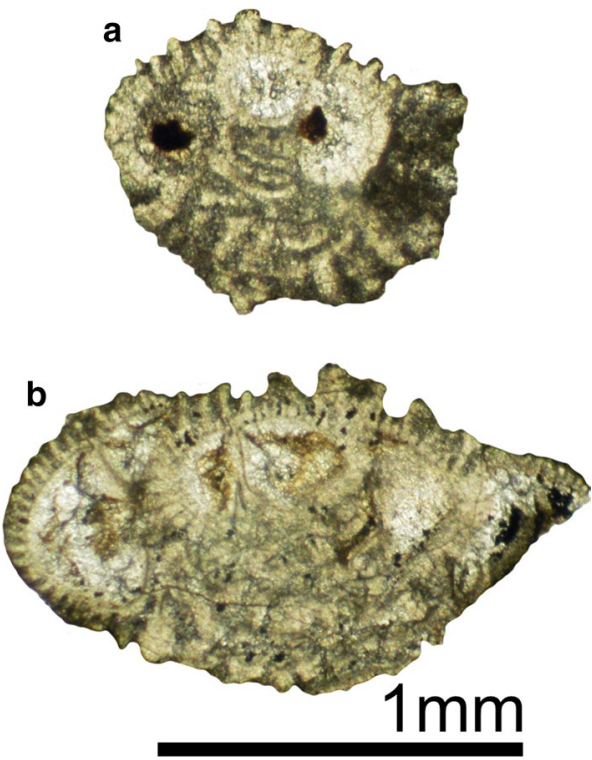

Fig. 21 Larger benthic foraminifer Lockhartia cf. diversa Smout from the upper Kheir Formation. a Sample well 1 (21.3). b Sample well 2 (242.9). Scale bar $=1 \mathrm{~mm}$ graphic dating, as they might provide new insight into the supposed sedimentary gap between the shallowmarine carbonates and the overlying hemipelagic units and would also provide other insights into the general basin evolution.

Acknowledgements We wish to thank the Zueitina Oil Company for providing the investigated samples and for permission to publish the data. The exact location of the study area, the exact position of the wells, and sample depths are confidential. We wish to thank Heinemann Oil GmbH for initiating the study and for financial support. Careful and thorough reviews by Andrea Benedetti (Modena) and Lorenzo Consorti (Rome) greatly improved the quality of the manuscript.

Funding Open access funding provided by Montanuniversität Leoben.

Open Access This article is licensed under a Creative Commons Attribution 4.0 International License, which permits use, sharing, adaptation, distribution and reproduction in any medium or format, as long as you give appropriate credit to the original author(s) and the source, provide a link to the Creative Commons licence, and indicate if changes were made. The images or other third party material in this article are included in the article's Creative Commons licence, unless indicated otherwise in a credit line to the material. If material is not included in the article's Creative Commons licence and your intended use is not permitted by statutory regulation or exceeds the permitted use, you will need to obtain permission directly from the copyright holder. To view a copy of this licence, visit http://creativecommons.org/licenses/by/4.0/.

\section{References}

Abadi AM, Van Wees J-D, van Dijk PM, Cloetingh SAPL (2008) Tectonics and subsidence evolution of the Sirt basin. Libya AAPG Bull 92(8):993-1027

Abugares YI (1996) Sedimentology and hydrocarbon potential of the Gir Formation, Sirt Basin, Libya. In: Salem MJ, El-Hawat AS, Sbeta AM (eds) The geology of the sirt basin: first symposium on the sedimentary basins of Libya, vol 2. Elsevier, Amsterdam, pp 45-64

Afzal J (2010) Evolution of larger benthic foraminifera during the Paleocene-early Eocene interval in the East Tethys (Indus Basin, Pakistan). Dissertation, University of Leicester

Aguirre J, Baceta JI, Braga JC (2007) Recovery of marine primary producers after the Cretaceous-Tertiary mass extinction: Paleocene calcareous red algae from the Iberian Peninsula. Palaeogeogr Palaeoclimatol Palaeoecol 249:393-411

Ahlbrandt TS (2001) The Sirte Basin province of Libya-Sirte-Zelten total petroleum system. US Geol Surv Bull 2202-F, pp 29

Ambrose G (2000) The geology and hydrocarbon habitat of the Sarir Sandstone, SE Sirt Basin. Libya J Pet Geol 23(2):165-192

Baceta JI, Pujalte V, Bernaola G (2005) Paleocene coralgal reefs of the western Pyrenean basin, northern Spain: new evidence supporting an earliest Paleogene recovery of reefal ecosystems. Palaeogeogr Palaeoclimatol Palaeoecol 224:117-143

Bagherpour B, Vaziri MR (2012) Facies, paleoenvironment, carbonate platform and facies changes across Paleocene Eocene of the Taleh Zang Formation in the Zagros Basin, SW-Iran. Hist Biol 24:121-142

Banerjee S (1980) Stratigraphic Lexicon of Libya. Bulletin of the Department of Geological Research and Mining, Tripoli 
Barr FT, Weegar AA (1972) Stratigraphic nomenclature of the Sirte Basin. Petroleum Exploration Society of Libya, Tripoli, Libya, p 179

Beavington-Penney SJ, Racey A (2004) Ecology of extant nummulitids and other larger benthic foraminifera: applications in palaeoenvironmental analysis. Earth-Sci Rev 67:219-265

Bebout DG, Pendexter C (1975) Secondary carbonate porosity as related to Early Tertiary depositional facies, Zelten field, Libya. AAPG Bull 59:665-693

Benedetti A (2018) Eocene carbonate clasts in Oligocene siliciclastic sediments of the Trapani Basin (NW Sicily): depositional and stratigraphic significance. Facies 64:14

Benedetti A, Marino M, Pichezzi RM (2018) Paleocene to Lower Eocene larger foraminiferal assemblages from Central Italy: new remarks on biostratigraphy. Riv Ital Paleont Strat 124:73-90

Benedetti A, Consorti L, Schlagintweit F, Rashidi K (2020) Ornatorotalia pila $\mathrm{n}$. sp. from the late Palaeocene of Iran: ecological, evolutionary and paleobiogeographic inferences. Hist Biol. https://doi.org/10.1080/08912963.2020.1741572

Berggren WA, Aubert J (1975) Paleocene benthonic foraminiferal biostratigraphy, paleobiogeography and paleoecology of Atlantic-Tethyan regions: Midway-type fauna. Palaeogeogr Palaeoclimatol Palaeoecol 18:73-192

Bezan AM (1996) The Palaeocene sequence in Sirt Basin. In: Salem MJ, Mouzughi AJ, Hammuda OS (eds) The geology of the sirt basin: first symposium on the sedimentary basins of Libya, vol 2. Elsevier, Amsterdam, pp 97-118

Bosellini FR, Russo A (1992) Stratigraphy and Facies of an Oligocene Fringing Reef (Castro Limestone, Salento Peninsula, Southern Italy). Facies 26:145-166

Bosellini FR, Vescogni A, Kiessling W, Zoboli A, Di Giuseppe A, Papazzoni CA (2020) Revisiting reef models in the Oligocene of northern Italy (Venetian Southern Alps). Boll Soc Paleontol Ital 59(3):337-348

Brady TJ, Campbell NDJ, Maher CE (1980) Intisar 'D' oil field, Libya. In: Halbouty MT (ed) Giant oil and gas fields of the decade 1968-1978, AAPG Memoir 30, pp 843-861

Burchette TP, Wright VP (1992) Carbonate ramp depositional systems. Sediment Geol 79:3-57

Butterlin J, Monod O (1969) Biostratigraphie (Paléocene a Eocéne moyen) d'une coupe dans le Taurus de Beyşehir (Turquie). Etude des "Nummulites cordelées" et révision de ce group. Eclogae Geol Helv 62(2):583-604

Consorti L (2019) Köroğlu F (2019) Maastrichtian-Paleocene larger Foraminifera biostratigraphy and facies of the Şahinkaya Member (NE Sakarya Zone, Turkey): insights into the Eastern Pontides arc sedimentary cover. J Asian Earth Sci 183:103965

Corriero G, Pierri C, Mercurio M, Nonnis Marzano C, Tarantini SO, Gravina MF, Lisco S, Moretti M, De Giosa F, Valenzano E, Giangrande A, Mastrodonato M, Longo C, Cardone F (2019) A Mediterranean mesophotic coral reef built by non-symbiotic scleractinians. Sci Rep 9(1):3601. https://doi.org/10.1038/ s41598-019-40284-4

Ćosović V, Drobne K, Moro A (2004) Paleoenvironmental model for Eocene foraminiferal limestones of the Adriatic carbonate platform (Istrian Peninsula). Facies 50:61-75

Cumings ER, Shrock RR (1928) Niagaran coral reefs of Indiana and adjacent states and their stratigraphic relations. Bull Geol Soc Am 39:579-620

Di Carlo M, Accordi G, Carbone F, Pignatti J (2010) Biostratigraphic analysis of Paleogene lowstand wedge conglomerates of a tectonically active platform margin (Zakynthos Island, Greece). J Mediterr Earth Sci 2:31-92

Drobne K (1977) Alvéolines paléogènes de la Slovénie et de l'Istrie. Mém Suisses Pal 99:132
Dunham RJ (1962) Classification of carbonate rocks according to depositional texture. In: Ham WE (ed) Classification of Carbonate Rocks, AAPG Memoir 1, pp 108-121

Eder W, Hohenegger J, Briguglio A (2018) Test flattening in the larger foraminifer Heterostegina depressa: predicting bathymetry from axial sections. Paleobiology 44(1):76-88

El-Hawat AS, Pawellek T (2004) A field guidebook to the geology of Sirt Basin, Libya. RWE, DEA N/ME

Flügel E (1982) Microfacies Analysis of Limestone. Springer, New York, p 633

Flügel E (2004) Microfacies of carbonate rocks: analysis, interpretation and application. Springer, Berlin, p 976

Ghose BK (1977) Paleoecology of the Cenozoic reefal foraminifers and algae - a brief review. Palaeogeogr Palaeoclimatol Palaeoecol 22:231-256

Gras R, Thusu B (1998) Trap architecture of the Early Cretaceous Sarir Sandstone in the eastern Sirt Basin, Libya. In: MacGregor DS, Moody RTJ, Clark-Lowes DD (eds) Petroleum geology of North Africa, vol 132. Geological Society, Special Publications, London, pp 317-334

Gumati YD (1992) Lithostratigraphy of oil-bearing Tertiary bioherms in the Sirte Basin. Libya J Pet Geol 15(3):305-318

Halbouty MT, King RE, Klemme HD, Dott RH, Meyerhoff AA (1970) Factors affecting formation of giant oil and gas fields, and basin classification. In: Halbouty MT (ed) Geology of giant petroleum fields-a symposium. AAPG Memoir 14, pp 528-555

Hallett D (2002) Petroleum geology of Libya. Elsevier Science B.V, Amsterdam, p 503

Hallett D, Clark-Lowes D (2016) Petroleum geology of Libya, 2nd edn. Elsevier Inc., Amsterdam, p 404

Harding TP (1984) Graben hydrocarbon occurrences and structural styles. AAPG Bull 68(3):333-362

Hohenegger J (2009) Functional shell geometry of symbiont bearing benthic Foraminifera. Galaxea (japan) 11:81-89

Hottinger L (1960) Recherches sur les Alvéolines du Paléocène et de l'Eocène. Mém Suisses Pal 75(76):243

Hottinger L (1983) Processes determining the distribution of larger foraminifera in space and time. Utrecht Micropaleontol Bull 30:239-253

Hottinger L (1997) Shallow benthic foraminiferal assemblages as signals for depth of their deposition and their limitations. Bull Soc Géol Fr 168:491-505

Hottinger L (2006) The depth-depending ornamentation of some lamellar-perforate foraminifera. Symbiosis 42:141-151

Hottinger L (2009) The Paleocene and earliest Eocene foraminiferal family Miscellaneidae: neither nummulites nor rotaliids. Carnets De Geol. https://doi.org/10.4267/2042/28794

Hottinger L (2014) Paleogene larger rotaliid foraminifera from the western and central Neotethys. Springer International, Berlin

Langenkamp RD (1994) Handbook of oil industry terms and phrases, 5 th edn. PennWell, Tulsa

Less G (1998) The zonation of the Mediterranean Upper Paleocene and Eocene by Orthophragminae. Slovenska Akademija Znanosti in Umetnosti, Razred Za Naravoslovne Vede Dela 34(2):21-43

Less G, Özcan E, Báldi-Beke M, Kollányi K (2007) Thanetian and early Ypresian orthophragmines (Foraminifera: Discocyclinidae and Orbitoclypeidae) from the central Western Tethys (Turkey, Italy and Bulgaria) and their revised taxonomy and biostratigraphy. Riv Ital Paleontol S 113(3):419-448

Liebau A (1984) Grundlagen der Ökobathymetrie. Paläontologische Kursbücher 2:149-184

Machaniec E, Jach R, Gradziński M (2011) Morphotype variation of orthophragminids as a paleoecological indicator: A case study of Late Bartonian limestone, Pod Capkami Quarry, Tatra Mts, Poland. Ann Soc Geol Pol 81(2):199-205 
Mresah MH (1993) Facies patterns and stratal geometries: Clues to the nature of the platform margin during the Paleocene, northeast Sirte Basin, Libya. Sediment Geol 84:149-167

Mresah MH (1998) The massive dolomitization of platformal and basinal sequences; proposed models from the Paleocene, northeast Sirte Basin, Libya. Sediment Geol 116:199-226

Özcan E, Less G, Okay AI, Yılmaz IÖ (2010) Stratigraphy and larger foraminifera of the Eocene shallow-marine and olistostromal units of the southern part of the Thrace Basin, NW Turkey. Turk J Earth Sci 19:27-77

Papazzoni CA, Cosovic V, Briguglio A, Drobne K (2017) Towards a calibrated larger foraminifera biostratigraphic zonation:celebrating 18 years of the application of shallow benthic zones. Palaios $32: 1-5$

Pawellek T (2009) From thin sections to discovery: the Upper Satal in the central Sirte Basin (north-central Libya) - a success story. Geotectonic Res 96:87-100

Perry CT (1999) Biofilm-related calcification, sediment trapping and constructive micrite envelopes: a criterion for the recognition of ancient grass-bed environments? Sedimentology 46:33-45

Pignatti J, Papazzoni CA (2017) Oppelzones and their heritage in current larger foraminiferal biostratigraphy. Lethaia 50:369-380

Pomar L (2001) Types of carbonate platforms, a genetic approach. Basin Res 13:313-334

Pomar L, Baceta JI, Hallock P, Mateu-Vicens G, Basso D (2017) Reef building and carbonate production modes in the west-central Tethys during the Cenozoic. Mar Pet Geol 83:261-304

Renema W, Troelstra SR (2001) Larger foraminifera distribution in a mesotrophic carbonate shelf in SW Sulawesi. Palaeogeogr Palaeoclimatol Palaeoecol 175:125-146

Riding R (2002) Structure and composition of organic reef and carbonate mud mounds: concepts and categories. Earth-Sci Rev $58: 163-231$

Rusk DC (2001) Libya: Petroleum potential of the underexplored basin centers-a twenty-first-century challenge. In: Downey MW, Threet JC, Morgan WA (eds) Petroleum provinces of the twentyfirst century, AAPG Memoir 74, pp 429-452

Sanders D, Baron-Szabo R-C (2005) Scleractinian assemblages under sediment input: their characteristics and relation to the nutrient input concept. Paleogeogr Paleoclimatol Paleoecol 216:139-181

Scheibner C, Reijmer JJG, Marzouk AM, Speijer RP, Kuss J (2003) From platform to basin: the evolution of a Paleocene carbonate margin (Eastern Desert, Egypt). Int J Earth Sci 92:624-640

Scheibner C, Rasser MW, Mutti M (2007) The Campo section (Pyrenees, Spain) revisited: Implications for changing benthic carbonate assemblages across the Paleocene-Eocene boundary. Paleogeogr Paleoclimatol Paleoecol 248:145-168

Schlager W (1981) The paradox of drowned reefs and carbonate platforms. Geol Soc Am Bull 92:197-211

Schlager W (2010) Ordered hierarchy versus scale invariance in sequence stratigraphy. Int J Earth Sci 99:139-151

Serra-Kiel J, Hottinger L, Caus E, Drobne K, Ferrandez C, Jauhri AK, Less G, Pavlovec R, Pignatti J, Samso JM, Schaub H, Sirel E, Strougo A, Tambareau Y, Tosquella J, Zakrevskaya E (1998) Larger Foraminiferal biostratigraphy of the Tethyan Palaeocene and Eocene. Bull Soc Géol Fr 169(2):281-299

Serra-Kiel J, Vicedo V, Baceta JI, Bernaola G, Robador A (2020) Paleocene Larger Foraminifera from the Pyrenean Basin with a recalibration of the Paleocene Shallow Benthic Zone. Geol Acta 18(8):1-69

Sirel E (2009) Reference sections and key localities of the Paleocene Stages and their very shallow/shallow water three new benthic foraminifera in Turkey. Rev Paléobiol 28(2):413-435

Sirel E (2012) Seven new larger benthic foraminiferal genera from the Paleocene of Turkey. Rev De Paleobiologie 31(2):267-301
Sirel E, Acar S (2008) Description and Biostratigraphy of the Thanetian-Bartonian Glomalveolinids and Alveolinids of Turkey. Scientific Synthesis of the Lifelong Achievement, TMMOB, UCTEA, Special 2:108

Sirel E, Deveciler A (2018) Diagnostic structural elements of Ranikothalia Caudri and redescription of its six species from Thanetian-Ilerdian of Turkey. J Palaeontol Soc India 63(1):19-36

Sirel E (1998) Foraminiferal description and biostratigraphy of the Paleocene-Eocene shallow water limestones and discussion of the Cretaceous-Tertiary boundary in Turkey. Mineral Research and Exploration (MTA), General Directorate, Ankara, Monography Series 2, pp 117

Sluijs A et al (2008) Eustatic variations during the Paleocene-Eocene greenhouse world. Paleoceanography 23:PA4216. https://doi.org/ 10.1029/2008PA001615

Španiček J, Ćosović V, Mrinjek E, Vlahović I (2017) Early Eocene evolution of carbonate depositional environments recorded in the Čikola Canyon (North Dalmatian Foreland Basin, Croatia). Geol Croat 70:11-25

Spring D, Hansen OP (1998) The influence of platform morphology and sea level on the development of a carbonate sequence: the Harash Formation, eastern Sirte Basin, Libya. In: MacGregor DS, Moody RTJ, Clark-Lowes DD (eds) Petroleum geology of North Africa, vol 132. Geological Society, Special Publications, London, pp 335-354

Swei GH (2010) Sedimentology and Petroleum Geology of the Gialo Formation (Middle Eocene) Sirt Basin, Libya. Dissertation, Durham University

Terry CE, Williams JJ (1969) The Idris 'A' bioherm and oilfield, Sirte Basin, Libya; its commercial development, regional Palaeocene geologic setting and stratigraphy. In: Hepple P (ed) The exploration for petroleum in Europe and North Africa. Institute of Petroleum, London, pp 31-48

Vescogni A, Bosellini FR, Papazzoni CA, Giusberti L, Roghi G, Fornaciari E, Dominici S, Zorzin R (2016) Coralgal buildups associated with the Bolca Fossil-Lagerstätten: new evidence from the Ypresian of Monte Postale (NE Italy). Facies 62:21

Vicedo V, Robles-Salcedo R, Serra-Kiel J, Hidalgo C, Razin Ph, Grélaud C (2021) Biostratigraphy and Evolution of the Larger Rotaliid Foraminifera in the Cretaceous Paleogene transition of the Southern Oman mountains. Pap Palaeontol 7(1):1-26

Vršič A, Machaniec E, Gawlick H-J (2021) Middle to Late Paleocene larger benthic foraminifera from the Sirt Basin (Libya). Rev De Micropaleontol 71:100481

Wenger LM, Pottorf RJ, Macleod G, Otten G, Dreyfus S, Justwan H, Wood ES (2009) Drill-bit metamorphism: recognition and impact on show evaluation. SPE ATCE. https://doi.org/10.2118/ 125218-MS

Wilson JL (1974) Characteristics of carbonate-platform margins. AAPG Bull 58(5):810-824

Wilson JL (1975) Carbonate facies in geologic history. Springer, New York, $\mathrm{p} 471$

Zamagni J, Mutti M, Kosir A (2008) Evolution of shallow benthic communities during the Late Paleocene-earliest Eocene transition in the Northern Tethys (SW Slovenia). Facies 54:25-43

Zamagni J, Košir A, Mutti M (2009) The first microbialite-coral mounds in the Cenozoic (Uppermost Paleocene) from the Northern Tethys (Slovenia): environmentally triggered phase shifts preceding the PETM? Palaeogeogr Palaeoclimatol Palaeoecol 274:1-17

Zamagni J, Mutti M, Košir A (2012) The evolution of mid Paleocene-early Eocene coral communities: How to survive during rapid global warming. Palaeogeogr Palaeoclimatol Palaeoecol $317-318: 48-65$ 